Review

\title{
Increasing the Power of Polyphenols through Nanoencapsulation for Adjuvant Therapy against Cardiovascular Diseases
}

\author{
Lucileno Rodrigues Trindade, Davi Vieira Teixeira da Silva, Diego dos Santos Baião \\ and Vania Margaret Flosi Paschoalin *(i)
}

Citation: Trindade, L.R.; da Silva, D.V.T.; Baião, D.d.S.; Paschoalin, V.M.F. Increasing the Power of Polyphenols through Nanoencapsulation for Adjuvant Therapy against Cardiovascular Diseases. Molecules 2021, 26, 4621. https://doi.org/10.3390/ molecules26154621

Academic Editors: Marisa Freitas, Daniela Ribeiro and Eduarda Fernandes

Received: 20 June 2021

Accepted: 27 July 2021

Published: 30 July 2021

Publisher's Note: MDPI stays neutral with regard to jurisdictional claims in published maps and institutional affiliations.

Copyright: (c) 2021 by the authors. Licensee MDPI, Basel, Switzerland. This article is an open access article distributed under the terms and conditions of the Creative Commons Attribution (CC BY) license (https:/ / creativecommons.org/licenses/by/ $4.0 /)$.
Chemistry Institute, Federal University of Rio de Janeiro, Avenida Athos da Silveira Ramos 149, Cidade Universitária, Rio de Janeiro 21941-909, Brazil; lucileno.trindade@gmail.com (L.R.T.); davivieira@ufrj.br (D.V.T.d.S.); diegobaiao20@ufrj.br (D.d.S.B.)

* Correspondence: paschv@iq.ufrj.br; Tel.: +55-21-3938-7362; Fax: +55-21-3938-7266

\begin{abstract}
Polyphenols play a therapeutic role in vascular diseases, acting in inherent illness-associate conditions such as inflammation, diabetes, dyslipidemia, hypertension, and oxidative stress, as demonstrated by clinical trials and epidemiological surveys. The main polyphenol cardioprotective mechanisms rely on increased nitric oxide, decreased asymmetric dimethylarginine levels, upregulation of genes encoding antioxidant enzymes via the Nrf2-ARE pathway and anti-inflammatory action through the redox-sensitive transcription factor NF- $\mathrm{BB}$ and PPAR- $\gamma$ receptor. However, poor polyphenol bioavailability and extensive metabolization restrict their applicability. Polyphenols carried by nanoparticles circumvent these limitations providing controlled release and better solubility, chemical protection, and target achievement. Nano-encapsulate polyphenols loaded in food grade polymers and lipids appear to be safe, gaining resistance in the enteric route for intestinal absorption, in which the mucoadhesiveness ensures their increased uptake, achieving high systemic levels in nonmetabolized forms. Nano-capsules confer a gradual release to these compounds, as well as longer half-lives and cell and whole organism permanence, reinforcing their effectiveness, as demonstrated in pre-clinical trials, enabling their application as an adjuvant therapy against cardiovascular diseases. Polyphenol entrapment in nanoparticles should be encouraged in nutraceutical manufacturing for the fortification of foods and beverages. This study discusses pre-clinical trials evaluating how nano-encapsulate polyphenols following oral administration can aid in cardiovascular performance.
\end{abstract}

Keywords: nanocarriers; antioxidants; bioavailability; cardiovascular health; polyphenol-loaded nanoparticles; pre-clinical trials

\section{Introduction}

Natural bioactive agents are attractive molecules, as their implicit safe status allows them to be tested as specific or multiple target regulators in signaling or functional human pathways, while also comprising promising therapeutic adjuvant candidates against multifactorial and complex physiopathological conditions, including degenerative diseases and metabolic dysfunctions. In food matrices, natural bioactive compounds contribute to color [1], bitterness, astringency [2], flavor [3], preservation, and safety [4]. Among the various naturally available bioactive molecules, polyphenols, which are secondary metabolites present in edible roots and plants, are associated with decreased risks concerning chronic, degenerative, and cardiovascular diseases when consumed regularly [5-7]. A large number of clinical trials have highlighted the therapeutic role of polyphenols on vascular disorders, playing a role in inherent illness-associate conditions such as inflammation, type 2 diabetes, dyslipidemia, hypertension, and oxidative stress [8-11]. Such findings have been compiled and reinforced in recent epidemiological data and meta-analysis [12-15].

Several mechanisms are involved in the cardioprotective role of polyphenols. These compounds increase nitric oxide (NO) release and vasodilation in endothelial cells 
through several nitric oxide synthase (eNOS) effects, including gene expression, catalysis activation by phosphorylation of the eNOS Ser1179 residue, and decreased asymmetric dimethylarginine (ADMA) levels, and an eNOS inhibitor, by increasing dimethylarginine dimethylamino hydrolase (DDAH) activity [16-20]. In addition, polyphenols positively regulate the expression of antioxidant enzymes by modulating the nuclear factor erythroid-2-related factor-antioxidant response element (Nrf2-ARE) [21]. Polyphenols also downregulate the inflammatory response, excessive reactive oxygen species (ROS) generation, and the activation of the redox-sensitive transcription factor nuclear kappa $B$ (NF-kB), the master inflammatory response regulator [22]. Polyphenols also regulate lipid metabolism and diabetes, presumably through the expression and activation of the peroxisome proliferator-activated gamma receptor (PPAR- $\gamma$ ) [23-26]. Acting through these broad molecular mechanisms, polyphenols play a protective role against endothelial dysfunction and inflammation, resulting in cardiovascular protection (Figure 1).

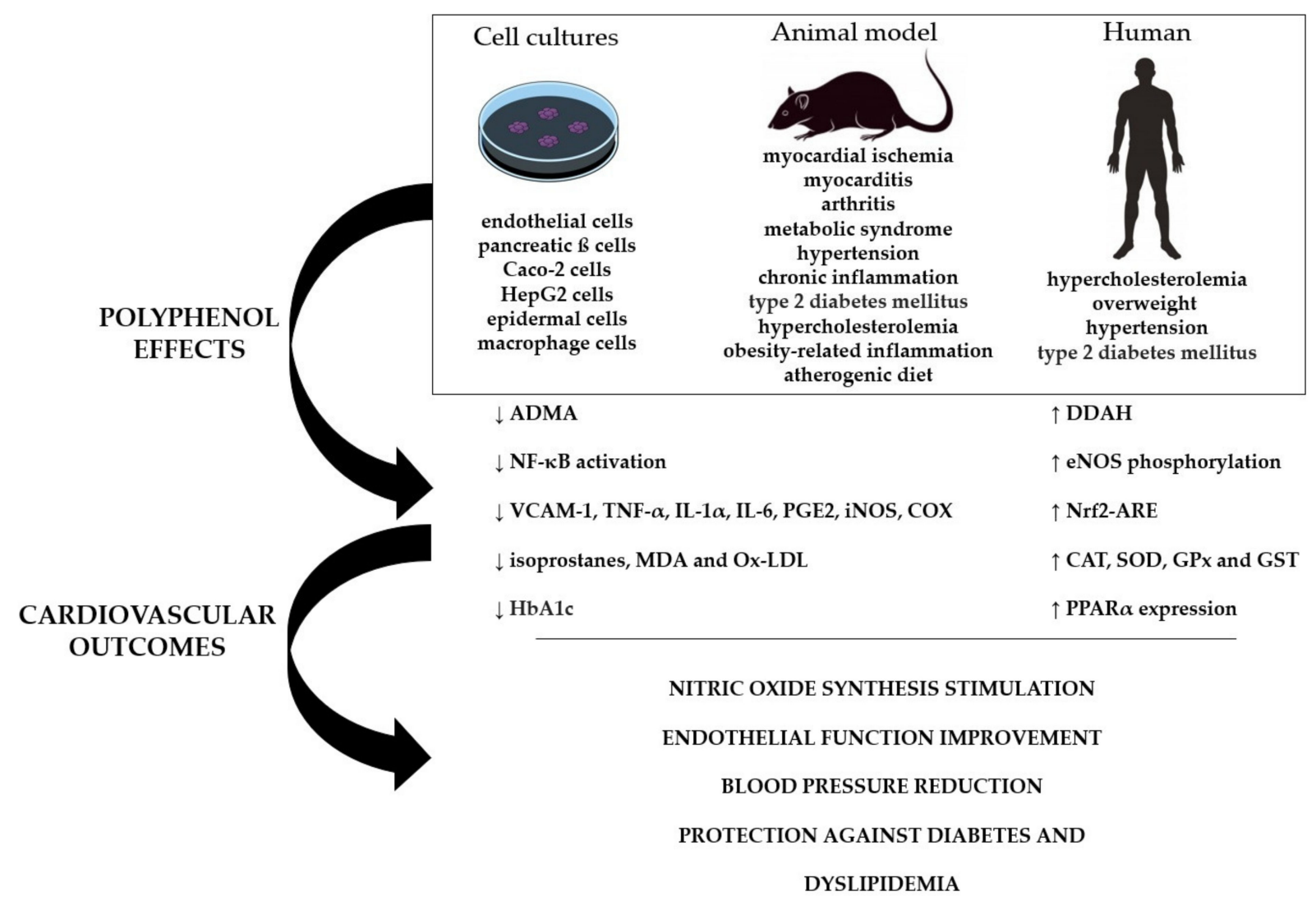

ANTI-INFLAMMATORY, ANTIPLATELET AND

ANTIATHEROGENIC ROLES

Figure 1. Protective role of polyphenols in different inflammatory and oxidative pathways in cells, animals, and humans that protect and improve the cardiovascular system.

Conversely, in vivo polyphenol performance may be limited due to the low hydrophilicity and poor intrinsic dissolution rate of these compounds or their physical or chemical instability $[27,28]$. In addition, these physicochemical characteristics may interfere in polyphenol bioavailability, as low absorption, scarce biodistribution, first-pass metabolism, poor penetration, and human organ accumulation should be expected [29-31].

Nano-encapsulation is a submicroscopic technology used to carry active solid or liquid substances into a 10-1000 nm colloidal system, termed nanoparticles (NPs) [32]. NPs can be classified as nanospheres or nano-capsules, according to the distribution of their active principles. If their active principles are uniformly adsorbed onto the surface or 
bound to polymeric chains, they are called nanospheres, but if they are confined within a cavity or core surrounded by a polymeric membrane, they are termed nano-capsules. Both are created from a single polymer or a combination of distinct polymers, both natural or synthetic [33] (Figure 2).

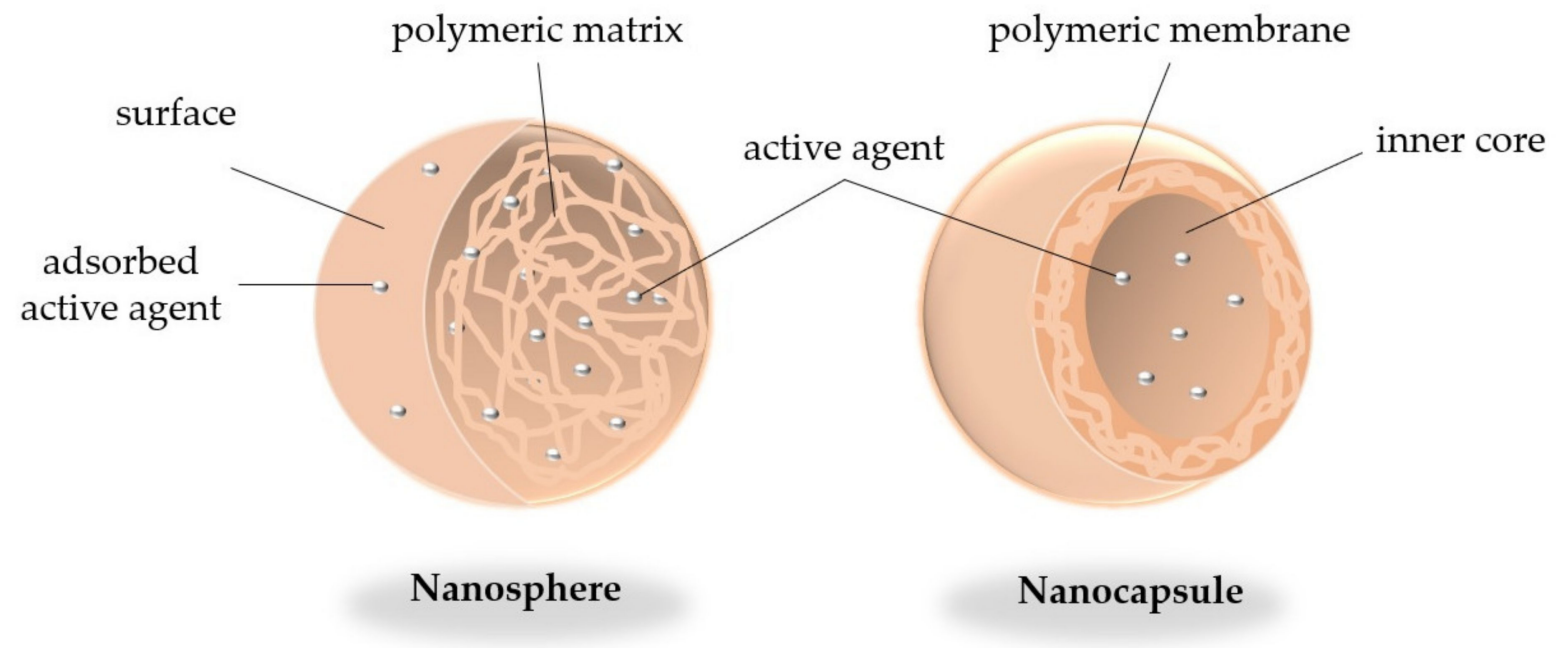

Figure 2. Nanospheres with the active agent adsorbed and dispersed on the polymeric surface (left); and nano-capsules with the active agent confined in the core surrounded by a polymeric membrane (right).

Nano-encapsulation has been substantially applied in the formulation of novel drugs and as a high-technology food input in order to protect bioactive compounds such as polyphenols, essential oils, peptides, oligonucleotides, and antioxidants from oxidation or lysis by external factors, including $\mathrm{pH}$, temperature variations, and exposure to light, ensuring their stability and increasing the half-lives of active principles. As a carrier system for therapeutic agents, nanoparticles can provide a controlled release of the active principle after oral, parenteral, or topical administration and, at the same time, guarantee better solubility and chemical structure stability, thus ensuring target achievement [33]. Due to their subcellular size similar to biomolecules, NPs are able to pass through the pores of the intestinal epithelium, cross biological barriers, including the blood-brain barrier, and penetrate tissues through microcapillaries, allowing for the delivery of therapeutic agents to specific organs and tissues and resulting in greater bioavailability [34-40]. It has been proposed that orally administered polyphenols are absorbed by transcellular diffusion in enterocytes and $\mathrm{M}$ cells and, to a lesser extent, by paracellular diffusion between cell junctions $[41,42]$.

Foods can be enriched in polyphenols by adding NPs carrying pure and concentrated polyphenols obtained from edible plants or food grade microorganisms, such as yeast or acid lactic bacteria, in order to protect polyphenols from oxidative degradation and conferring all the aforementioned stability and advantages [43].

The main natural (or food-grade) polymers obtained from plants and vegetables used to nano-encapsulate polyphenols are presented herein. The ability of these polymers to preserve polyphenol structure, bioactivity, and gastrointestinal bioaccessibility are addressed. The current framework concerning possible polyphenol gastrointestinal toxicity, bioavailability, and bioactivity addressed through clinical trials is reviewed and, finally, the projection of the performance of nano-encapsulated polyphenols in aiding cardiovascular impairments is discussed.

\section{Brief Overview of Nano-Encapsulated Polyphenols: Nature and Physiochemical Polymer Benefits}

Natural polymers, such as carbohydrates, proteins and lipids, are the most abundant organic matter in nature and essential for the existence of living organisms, as they perform 
vital functions such as comprising structural cell and tissue components and acting in transport and catalysis processes as energetic reserves and in energy transformation, among others [44]. Due to these characteristics and their biodegradability, biocompatibility, and non-toxicity, natural polymers have been chosen as the wall material and vehicle for drug and nutraceutical delivery in micro- and nanodevices. As mentioned previously, the entrapment of these polymers in nanoparticles ensures greater physical-chemical polyphenol stability in the gastrointestinal tract concerning enzymatic activities and the gastrointestinal environment itself, as well as in the bloodstream.

\subsection{Proteins}

Proteins such as gelatin, albumin, and casein are the most used proteins to obtain NPs. Gelatin is an encapsulant agent obtained from the partial hydrolysis of collagen and has been used to nano-encapsulate polyphenols alone or associated with surfactants and polysaccharides with opposite charges, such as cellulose, carboxymethylcellulose, chitosan, or arabic gum [45-48].

Polyphenol adsorption onto gelatin NPs occurs through the formation of hydrogen linkages between phenolic rings and hydrophobic amino acids [49]. Gelatin nano-capsules loaded with catechins from Camellia sinensis were formed spontaneously by homogenization under magnetic stirring of the polyphenol-protein mixture. The NPs were $140.5 \mathrm{~nm}$ in size, with a zeta potential of $0.2 \mathrm{mV}$, and over $96 \%$ of the catechin was encapsulated using a formulation containing $2 \mathrm{mg} \cdot \mathrm{mL}^{-1}$ of each compound. Hydrogen bonds between the phenolic and aliphatic hydroxyls of catechin and gelatin, respectively, allowed for the spontaneous formation of NPs without the use of surfactants and crosslinkers. The gelatin-catechin NPs retained their antioxidant activity as evaluated by $2,2^{\prime}$-azino-bis(3ethylbenzothiazoline-6-sulfonic) acid (ABTS) and 2,2-diphenyl-1-picrylhydrazyl (DPPH) assays after 3 weeks stored at room temperature, indicating the effectiveness of gelatin, concerning the chemical and bioactive stability of catechin [50]. An enriched polyphenol extract obtained from cocoa was successfully encapsulated with a gelatin and surfactant mixture (2:2:2 $w / v \%)$ followed by the addition of glutaraldehyde (0.125:1, glutaraldehyde:gelatin ratio), resulting in NPs with a uniform morphology and diameters ranging from 130 to $200 \mathrm{~nm}$ [51]. In that study, an encapsulation efficiency of $77 \%$ was observed, comparing the phenolic extract with the nano-encapsulated form through a DPPH analysis. The encapsulation efficiency and the diameter of gelatin-NPs can vary depending on the method, encapsulated agent, polymer concentration, and combination with surfactants and other wall materials. These variables explain the discrepancies observed regarding the encapsulation percentages and diameters reported in several studies.

Karthikeyan et al. [52] prepared $294 \mathrm{~nm}$ gelatin-NPs, with a polydispersity index (PDI) of 0.29 and zeta potential of $-18.6 \mathrm{mV}$, using glutaraldehyde as the crosslinking agent and span 80 to encapsulate $10 \mathrm{mg}$ of resveratrol. The release of resveratrol during the first $12 \mathrm{~h}$ ranged from $28 \%$ to $40 \%$, which can happen in a wide range from 1.4 to $10.5 \mathrm{pH}$. About $30 \%$ of resveratrol was quickly released, followed by a slower and sustained release up to $48 \mathrm{~h}$ achieving $63 \%$ to $80 \%$ of total resveratrol entrapped at alkaline $\mathrm{pH}$. The behavior exhibited by gelatin NPs can be advantageous in oral administration, due to the possibility of quickly reaching an effective resveratrol concentration, protecting it for a prolonged timeframe under unfavorable $\mathrm{pH}$ conditions. Song et al. [53] prepared gelatin NPs loaded with the flavonoids genistein and icariin by the desolvation method under $\mathrm{pH}$ variations $(2-5)$. The NPs were stable for 180 days at room temperature and uniform at $\mathrm{pH} 3.5$, with the smallest diameter of $231 \mathrm{~nm}$, (PDI of 0.104) and best zeta potential of $+29.61 \mathrm{mV}$. The adsorption capacity of the flavonoids increased with increasing gelatin NPs concentrations, exceeding $90 \%$ when gelatin NPs concentrations were over $3 \mathrm{~g} \cdot \mathrm{L}^{-1}$ and at temperature and incubation time above $20^{\circ} \mathrm{C}$ and $24 \mathrm{~h}$, respectively. The adsorption capacity of icariin was significantly higher than genistein, possibly due to the greater number of hydroxyl $(-\mathrm{OH})$ groups. The amounts of adsorbed genistein and icariin were greater than their individual adsorptions, most likely due to the presence of more hydrogen linkages 
between phenolic rings and hydrophobic amino acids [49]. This can be of paramount therapeutic importance due to the possibility of producing NPs composed of different polyphenol combinations with good physicochemical properties.

Other proteins used as polyphenol nano-encapsulant agents consist of human or bovine serum albumins, HSA and BSA, both presenting a molecular mass of $66.5 \mathrm{kDa}$, synthesized in the liver and representing the most abundant proteins in plasma [54]. Albumin participates in osmotic and colloidal plasma maintenance and in the transport of various endogenous compounds such as other proteins, cholesterol, and bile pigments through the bloodstream $[55,56]$. These proteins may act as nano-encapsulating polymers for nutritional supplementation and pharmaceutical purposes, as they improve the solubility of hydrophobic active agents and their circulation in the body, while allowing for better tissue targeting [57-59]. As an encapsulant, albumin exhibits chemical stability and the ability to form NPs without the use of other polymers or surfactants, although the latter contributes to forming smaller particles with low aggregation capacity [49,51].

BSA-NPs loaded with rutin were formulated by nano-spray drying by dissolving $5 \mathrm{mg}$ of rutin and $25 \mathrm{mg}$ of BSA in water $(6.6 \mathrm{~mL})$, ethanol $(3 \mathrm{~mL})$, and Tween-80 (0.4 mL). The NPs were $316 \mathrm{~nm}$ in size and only $32 \%$ of the rutin was encapsulated due to low affinity to BSA and thermal polyphenol degradation due to high spray drying temperatures $\left(100^{\circ} \mathrm{C}\right)$. Conversely, BSA-rutin NPs comprised a homogeneous and stable nano-capsule population (PDI 0.27) with a surface charge of $-32.1 \mathrm{mV}$. Rutin entrapment guaranteed a time control release and increased rutin IC50 by two-fold compared with free rutin for $72 \mathrm{~h}$, as determined by ABTS+ assays [60]. BSA-NPs containing quercetin were developed using the desolvation method, using $8 \%$ and $20 \%$ glutaraldehyde as the crosslinking agent, resulting in 152 and $132 \mathrm{~nm}$ NPs, respectively. Quercetin was efficiently encapsulated in both formulations $(>85 \%)$, exhibiting a monodispersed distribution and physical stability, as verified by a low PDI value $(<0.12)$ and high zeta potential $(\approx-40 \mathrm{mV})$. Quercetin was released in a second order kinetic rate, where $6 \%$ was released in the first $30 \mathrm{~min}$, followed by a slow $15 \%$ loss in the next $24 \mathrm{~h}$ and slower amount of $18 \%$ up to $96 \mathrm{~h}$. It seems that NP-adsorbed quercetin was rapidly released, whereas diffusion within NPs required the relaxation of the polymeric structure, slowing down quercetin release. Nano-encapsulation protected the quercetin antioxidant activity, as revealed by the ABTS radical inhibition assay compared with its free form at $\mathrm{pH}$ 7.4.

Thus, BSA-NPs maintain polyphenol molecule stability and allow for their controlled release, causing them to be gradually available to exert their physiological effects, while preserving their activity over time [61]. Acetaminophen, ipriflavone, daidzein, and genistein were successfully entrapped into BSA- and HSA-NPs, mostly through the desolvation method [62-64].

Curcumin nano-encapsulated in HSA $2 \%(w / w)$ and chloroform/water (1:19), freezedried, and stored for 3 months at room temperature displayed no morphological alteration concerning 130-150 nm nano-capsules formulated in chloroform/water (1:19). The prepared HSA-NPs enhanced curcumin solubility by 300 -fold and displayed cryoprotectant properties [65].

Caseins, the major milk phosphoproteins, exhibit a micellar structure ranging from 50 to $300 \mathrm{~nm}$, stabilized by hydrophobic interactions and bonds between calcium phosphate and serine residues, and have been applied in phenolic entrapment. Casein nanoparticles promote structural phenolic stability, enhancing their solubility and bioavailability [66-69]. Casein nano-capsules, sized $168.7 \mathrm{~nm}$ on average, were used to encapsulate curcumin, reaching up to $83 \%$ encapsulation efficiency by the spray drying method in a sodium caseinate and ethanol solution $(40 \% v / v)$. Non-encapsulated curcumin displayed a 40 -fold increased water dispersion, resulting in high antioxidant power as assayed by the Trolox assay $(8.87 \mathrm{mM})$ when compared with the free form $(<1 \mathrm{mM})$. The enhanced dispersion and uniform curcumin distribution in the reaction medium and surface area inherent to casein nano-capsules seem to facilitate the reaction kinetics and bioactivity of the active principle [70]. A similar protocol was successful applied in the entrapment of ferulic acid, 
resveratrol, and epigallocatechin in casein-NPs following spray-drying. The release of phenolics from casein-NPs seems to obey the Korsmeyer-Peppas kinetic model in a zeroorder reaction by relaxation and erosion of the polymeric matrix, with no $\mathrm{pH}$ influence from 1.2 to 6.8 [71].

A novel approach in the production of stable NPs in the gastrointestinal environment has been developed using a liquid-liquid dispersion method applied in the encapsulation of ferulic acid in a zein-casein-lysine matrix. The NPs were $199 \mathrm{~nm}$ in diameter, displaying a slow and prolonged release of $4 \%$ of the polyphenol for $48 \mathrm{~h}$ at physiological $\mathrm{pH}(\mathrm{pH}$ 7.4). The strong interaction between ferulic acid and the nano-capsule-matrix was a mandatory factor for its sustained release, maintaining polyphenol protection and, consequently, its biological effects for a long period of time. However, the lack of a kinetic profile determination at gastric $\mathrm{pH}$ comprises a study limitation regarding NP characterization and usage [72].

Finally, caseins were used to encapsulate the flavonoid epigallocatechin gallate (EGCG) alongside glucosamine (GA) at a 1:2:8 ratio $(w / w / w)$ in order to promote greater chemical stability. The NPs were $186 \mathrm{~nm}$ in size, displaying a high encapsulation efficiency $(86.8 \%)$ and zeta potential $(-35.8 \mathrm{mV}$ ) and were monodispersed (PDI 0.10), indicating feasibility in encapsulating a mixture of polyphenols. The formulation preserved $90 \%$ and $80 \%$ of EGCG for 15 and 45 days at $4{ }^{\circ} \mathrm{C}$, respectively, while totally degrading at $25^{\circ} \mathrm{C}$. When nano-encapsulation was followed by freeze-drying, 90\% of EGCG remained stable for 12 months at $25^{\circ} \mathrm{C}$ without any physicochemical changes [73].

\subsection{Polysaccharides}

Polysaccharides have also been widely used to develop capsules, mainly for biomedical and pharmaceutical purposes, due to their availability, low cost, and ability to form NPs. Alginates, chitosan, and starch are the most applied as nanocarriers for the oral delivery of polyphenols [74-76].

Alginate is anionic and water-soluble, and its popular use in obtaining NPs resides in its gelation ability in the presence of di- and trivalent cations under mild formulation conditions [77-80]. The combination of sodium alginate and chitosan, another carbohydrate polymer, is frequent, as it allows for NP formation by electrostatic bonding between the negatively charged alginate carboxyl groups and the protonated chitosan amines. Nonencapsulated alginate-chitosan compounds exhibit greater thermal stability and a continuous and controlled release profile $[81,82]$, and its application as a delivery vehicle for compounds with pharmacological properties favors cell uptake due to the mucoadhesiveness inherent to alginate and greater permeability provided by the association with chitosan [83-85]. Corroborating this, Das et al. [86] encapsulated curcumin through alginate and chitosan ion gelatinization, using pluronic F127 as a surfactant. NPs $100 \mathrm{~nm}$ in size exhibited a slow curcumin release, achieving $75 \%$ of the initial amount at $96 \mathrm{~h}$. Furthermore, these NPs were also absorbed by cell cultures. Considering systemic uses, these properties can enhance NP uptake by target cells and tissues, due to the longer permanence of the polyphenol in internal compartments.

The possibility of enriching NPs for the delivery of a mixture of hydrophobic polyphenols was tested by Saralkar and Dash [87]. Curcumin and resveratrol were encapsulated together in alginate-calcium chloride $\left(\mathrm{CaCl}_{2}\right)$ particles through gelatinization and emulsification with Tween-80, forming $57 \mathrm{~nm}$ NPs. Resveratrol was efficiently encapsulated compared to curcumin (70.9 vs. $49.3 \%)$, while curcumin exhibited a slower release rate throughout $24 \mathrm{~h}$ (16.3 vs. $87 \%$ ) and was better captured by cells compared resveratrol, demonstrating that alginate is a potential nanocarrier for hydrophobic polyphenols.

In an optimized methodological approach, quercetin was encapsulated by chitosan gelatinization using sodium tripolyphosphate (TPP) as a crosslinker, followed by polyelectrolytic complexation with sodium alginate using alginate-chitosan at a 1:2 ratio and quercetin at $7.5 \mathrm{mg} \cdot \mathrm{mL}^{-1}$ [88]. NPs ranged from 118 to $255 \mathrm{~nm}$ and high encapsulation efficiency $(82.4 \%)$, and quercetin was released in a biphasic pattern, reaching $78 \%$ in $8 \mathrm{~h}$ 
with the rest releasing gradually for up to $24 \mathrm{~h}$. In this formulation, alginate promoted chitosan stability at an acid $\mathrm{pH}$ (5.5-6.5), its soluble range, and prevented the early exposure of quercetin to the gastric environment and consequent enzymatic degradation.

Starch has been applied as a wall material in nanotechnology, due to its solubility, emulsification, and biocompatibility characteristics. Its versatility relies on its structural-derivatives, maltodextrin and cyclodextrin, obtained by physical and chemical methods [89,90]. The amylose and amylopectin ratio, as well as its branching pattern and molecular weights, can be managed to influence NP size and its ability to encapsulate and retain active agents [91-93]. As a polyphenol carrier, starch can improve bioaccessibility in the gastrointestinal fluid and maintain antioxidant capacity in addition to providing stability against harsh conditions such as heat, radiation, and hyperosmotic environments [75]. Starch-NPs $(1 \% w / v)$ loaded with curcumin $(0.25 \mathrm{mM})$ by nano-precipitation using ethanol, an oil mixture (cyclohexane, sunflower oil, and oleic acid), and a surfactant, formed $87 \mathrm{~nm}$ NPs with $78 \%$ loading efficiency. Due to high starch hydrophilicity, greater surface area, and reduced size, NPs exhibited greater interaction with aqueous media and resulted in higher curcumin solubility compared to its free form. In addition, the use of starch NPs allowed for a controlled curcumin release of approximately $93 \%$ for 10 days under physiological $\mathrm{pH}$ [94].

The loading capacity of starch depends on amylopectin content. Starch obtained from different edible vegetables such as pea (Pisum sativum), corn (Zea mays), and potato (Solanum tuberosum), have been applied in quercetin encapsulation by the nanoprecipitation method using 0.1 M HCL as the non-solvent. The higher the amylopectin content, the better the quercetin entrapment and antioxidant activity, as follows: potato (49\% loading) > pea (44\% loading) > corn (20\% loading) [95].

Other starch sources, such as water chestnut (Eleocharis dulcis), horse chestnut (Aesculus hippocastanum), and lotus stem (Nelumbo nucifera), have been used to encapsulate resveratrol, producing 691, 419, and $797 \mathrm{~nm}$ NPs, respectively, with an average encapsulation efficiency of $79 \%$. Nano-encapsulation provided thermal stability to resveratrol, observed by the increases in NP transition temperatures when exposed to $200{ }^{\circ} \mathrm{C}$ [96].

In addition to the aforementioned assays, starch has also been applied for the nanoencapsulation of catechin, epicatechin, EGCG, and proanthocyanidin nano-encapsulation, and the resulting NPs exhibited chemical stability under different conditions, confirming the viability of starch in polyphenol delivery [75].

Chitosan is widely applied for nano-encapsulation due to its physical-chemical characteristics, including the ability to form gels by ionic bonds and its cationic nature, conferring mucoadhesiveness through electrostatic interactions and favoring the interaction of the transported agent with the mucus layer of epithelial surfaces [97-100].

Chitosan-NPs are generally prepared by gelation with TPP, a crosslinking polyanion widely applied due to its non-toxicity, multivalence, and the ability to form a gel, as mentioned previously [101-103]. Ionic interactions also occur inside NPs between the chitosan-TPP matrix and the encapsulated polyphenol, through the hydrogen bonds of the OH groups [104,105]. Such interactions promote a slow (approx. $100 \mathrm{~h}$ ) and continuous NP release in addition to retaining antioxidant capacity and ensuring stability to prolonged exposure at high temperatures [105]. Chitosan is also used to deliver natural antibiotics, antioxidants, proteins, and dyes [106-108].

Recently, chitosan $\left(1 \mathrm{mg} \cdot \mathrm{mL}^{-1}\right)$ cross-linked with TPP $\left(0.5 \mathrm{mg} \cdot \mathrm{mL}^{-1}\right)$, was used to encapsulate quercetin and myricetin $\left(5 \mathrm{mg} \cdot \mathrm{mL}^{-1}\right)$, generating $123.75 \mathrm{~nm}$ and $153 \mathrm{~nm} \mathrm{NPs,}$ respectively. Both NPs exhibited high retention capacity greater in myricetin (89\% vs. 82\%) due to the presence of an extra hydroxyl in ring B, allowing for greater interaction with the positively charged matrix. The chitosan-TPP NPs provided a controlled polyphenol release at physiological pH (7.4) during $96 \mathrm{~h}$, contributing to their prolonged antioxidant effect in relation to free flavonoids [109].

Through a single-factor optimization algorithm, carboxymethyl chitosan (CMC) crosslinked with $\mathrm{CaCl}_{2}$ was used to encapsulate resveratrol. NPs sized $155 \mathrm{~nm}$ and exhibiting 
$44 \%$ encapsulation efficiency and a zeta potential of $-10.3 \mathrm{mV}$ were obtained using CMC and $\mathrm{CaCl}_{2}$ at $5 \mathrm{mg} \cdot \mathrm{mL}^{-1}, 10: 1$ water/chloroform and 1:1000 water/surfactant. The antioxidant activity of resveratrol was substantially maintained in the formulated NPs compared with free resveratrol [110].

Similarly, He et al. [111] applied the response surface methodology mathematical model to establish anthocyanin, $\mathrm{CMC}$, and chitosan chloridate $(\mathrm{CHC})$ concentrations for the synthesis of stable NPs in beverages, with maximum anthocyanin encapsulation efficiency and minimum particle size. CMC, CHC, and anthocyanins were found to be optimal for the synthesis of NPs at $2.86,0.98$, and $5.97 \mathrm{mg} \cdot \mathrm{mL}^{-1}$, respectively, resulting in $219 \mathrm{~nm}$ sized NPs and $63 \%$ encapsulation. The anthocyanin-NPs were highly stable beverages, maintaining $84 \%$ encapsulation for 35 days at $4{ }^{\circ} \mathrm{C}, 68.4 \%$ for 12 days at $25^{\circ} \mathrm{C}$, and $30 \%$ for 9 days at $40{ }^{\circ} \mathrm{C}$. However, free anthocyanins were less stable, at $71.2 \%, 49.7 \%$, and $6.3 \%$ under the same conditions [111].

Other polyphenols, such as gallic acid, catechin, procyanidins, ferulic acid, quercetin, and polyphenols from green tea extract (Camellia sinensis) have also been tested as active agents in chitosan NPs [112-117]. In short, chitosan NPs are able to effectively encapsulate polyphenols, providing thermal stability, stability in suspensions, solubility, and sustained release, while still retaining antioxidant polyphenol properties. Therefore, chitosan-NPs represent a promising vehicle for polyphenol delivery as they fulfill the criteria for safe nano-encapsulating natural matrices, such as biocompatibility and non-toxicity, in addition to providing bioavailability and cost-effectiveness.

\subsection{Nanoemulsions}

Nanoemulsions (NEs) are a colloidal system synthetized by the dispersion of two immiscible liquids, such as oil and water, stabilized by a surfactant compound, forming droplets ranging from 20 to $100 \mathrm{~nm}$. In this system, the active principle, a hydrophilic or hydrophobic molecule, is dissolved in water or oil, and the active solvent is then emulsified in water (oil-in-water) or oil (water-in-oil) in the presence of surfactants [118] (Figure 3). In the food industry, NEs have been applied to improve the solubility, stability, bioavailability, and functional property of many bioactive compounds incorporated in beverages, sauces, desserts, and dairy products, as well as for the fortification, texture enhancement, and overall product quality of these foodstuffs [118,119].

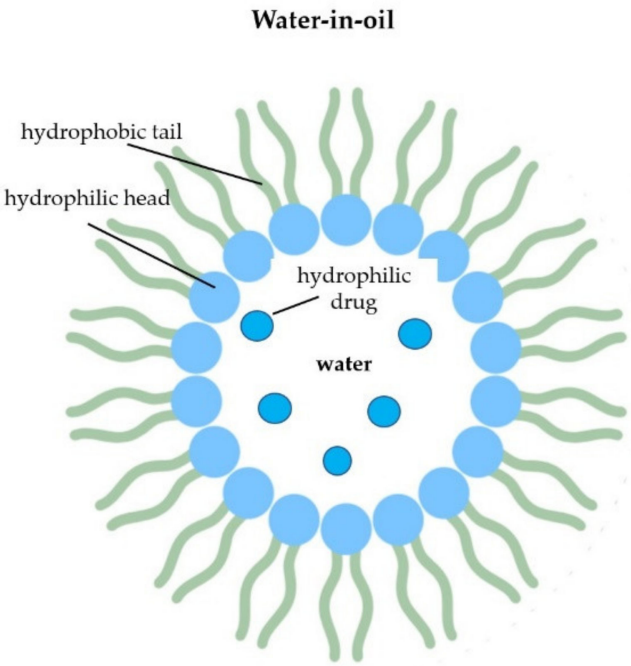

(A)

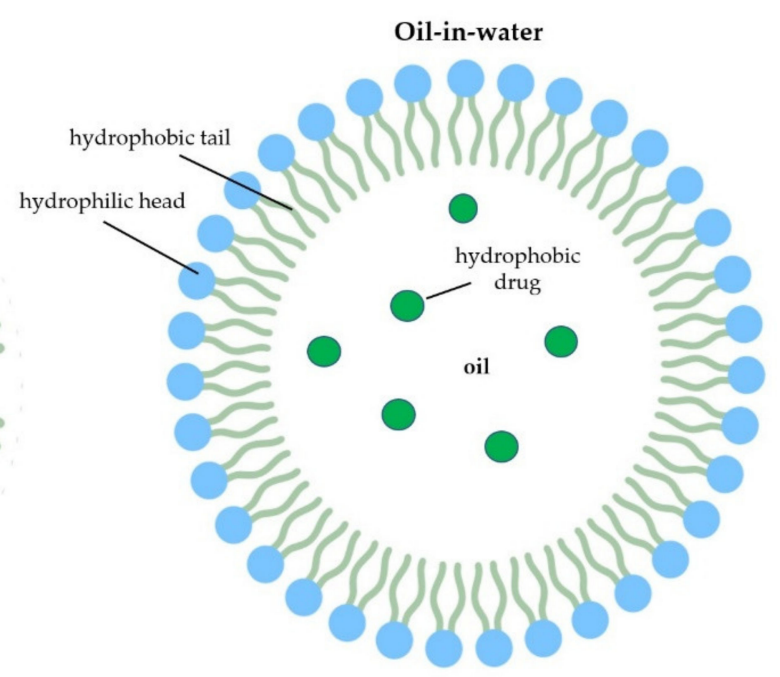

(B)

Figure 3. Schematic representation of nanoemulsions. Water-in-oil, where water and a hydrophilic compound are dispersed in an oily medium (A) and oil-in-water, in which the oil and the hydrophobic compound is dispersed in an aqueous phase (B). 
Peanut, corn, olive, and sesame oils and medium chain triglycerides (6 to $12 \mathrm{C}$ ) are commonly used as active principle-lipid coatings, while Tween-20, Tween-80, glycerol monooleate, soya lecithin, and polyoxyethylene can be employed as emulsifiers to stabilize the oil-water interface $[120,121]$. Encapsulation improves the solubilization of hydrophobic functional compounds, protecting them against oxidation and gastrointestinal tract chemical modifications, increasing their bioavailability [122]. Polyphenols are good candidates to be transported in NEs due to their good lipophilicity and their inherent stability limitations and water insolubility as well as their low bioaccessibility and bioavailability, which can be resolved by lipid encapsulation [123].

In this sense, tea polyphenols from Camellia sinensis (400 mg) were encapsulated in corn oil using water and polysorbate 80 (oil-in-water), generating stable $99.4 \mathrm{~nm} \mathrm{NEs,}$ which display no significant size modifications, aggregation, or $\mathrm{pH}$ after 20 days of storage at 4,25 , or $40^{\circ} \mathrm{C}$ [124]. Trans-resveratrol has also been incorporated into oil-in-water NEs, generating $241 \mathrm{~nm}$ nanoparticles with $99.9 \%$ efficiency encapsulation. NEs were synthesized by the interfacial deposition method, in which trans-resveratrol was incorporated into a matrix consisting of poly(e-caprolactone), triglyceride, sorbitan monostearate, and polysorbate 80 . The trans-resveratrol in the NEs was stable for 90 days at room temperature, exhibiting no physical-chemical changes [125].

According to Sessa et al. [126], the trans-resveratrol encapsulated in different foodgrade NEs generated by high pressure homogenization and containing peanut oil and emulsifiers soy lecithin, glycerol monooleate, and sugar ester exhibit stable diameters (150-270 nm) at 4, 30, and $55^{\circ} \mathrm{C}$ after 30 days in comparison with NEs containing a synthetic emulsifier ( $>50 \mathrm{~nm}$ ), demonstrate the superior technological quality conferred by naturally available food-grade compound NEs concerning shelf life. In addition, the oxidative stability of trans-resveratrol in NEs $(0.01 \%)$ is greater according to increasing amounts of peanut oil (9-27.9\%) and soy lecithin (1-2.1\%), reaching 92\% stability under storage and ultraviolet (UV) light compared with both free resveratrol and that encapsulated by the synthetic emulsifier formulation, reported as $45 \%$ and $82 \%$, respectively.

Biocompatible NEs developed using isopropyl myristate combined to ionic and nonionic surfactants (Tween-80, labrasol, and maisine) plus transcutol as an aqueous solvent (oil-in-water) were produced for curcumin encapsulation by emulsification at low energy. Curcumin-loaded NEs were $165 \mathrm{~nm}$ in size, with a low PDI of 0.072 and stable for 60 days at room temperature [127]. This indicates that NEs from food grade are good alternatives for polyphenol encapsulation due to facilitated production under mild processing conditions, resulting in high encapsulation efficiency and physicochemical stability [122,126,128].

\subsection{Nanoliposomes and Niosomes}

Liposomes are used in the agricultural, food, and pharmaceutical industries as carriers for both nucleic acids and nutraceutical products such as vitamins, proteins and enzymes, and whole herbal extracts [129]. Due to their similarity to biological membranes, liposomes are considered the standard gold model for cell membrane studies and human applications $[130,131]$. These spherical lipid vesicles contain homocentricly arranged phospholipid bilayers around an aqueous core with the polar heads of the phospholipids located on the outer and inner surfaces of the membranes in contact with the aqueous environment, while fatty acids form the hydrophobic core of the membranes, resulting in liposome amphiphilicity and allowing the encapsulation of hydrophilic or lipophilic agents [132,133] (Figure 4). 


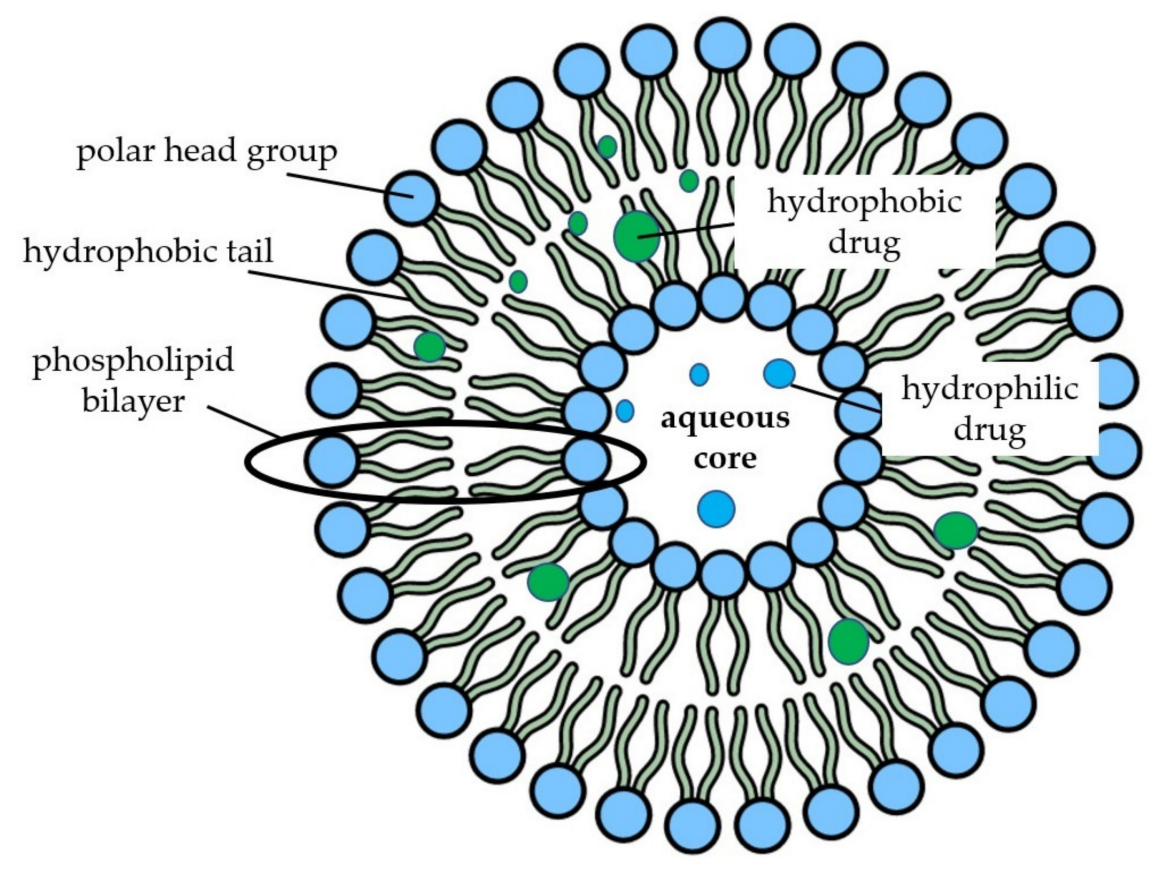

Figure 4. Schematic representation of nanoliposomes containing hydrophilic and hydrophobic entrapped compounds.

The main liposome components are lipids or phospholipids that can contain sterols incorporated in their structure. Cholesterol is the most widely used sterol in liposome syntheses, as it mimics the cell membrane and increases the stability of the lipid structure by modulating the lipid bilayer fluidity [134].

In addition, niosomes, self-assembled vesicles, are formed by hydration of non-ionic surfactant, cholesterol, or other amphiphilic molecules and are able to transport both hydrophilic and hydrophobic molecules. Their chemical stability, easy preparation and lowcost production make them versatile nanocarriers for the delivery of drugs and bioactive compounds by several routes including oral, ocular, topical, pulmonary, parenteral, and transmucosal [135-137].

There is evidence that NLs may comprise good delivery nanodevices to supplement polyphenols in a safe and quick way to individuals presenting inflammatory and oxidative conditions [138].

Nanoliposomes (NLs) and liposomes display identical chemical structures and thermodynamic properties, but the former exhibit greater surface area, stability, solubility, bioavailability, delayed body clearance, and precision targeting $[139,140]$. In this context, NLs are employed to improve the stability, poor water solubility, and oral bioavailability of many polyphenols [141,142].

Mucus is the first barrier for nutrients from the oral route. Curcumin-NLs with improved stability and mucoadhesive properties were synthesized through encapsulation in L- $\alpha$-phosphatidylcholine at a 1:10 $(w / w)$ ratio with chitosan $(0.1 \%)$ by the ethanol injection method. These NLs displayed $123 \mathrm{~nm}$ average diameter, PDI reduced to 0.2 and stability at $4{ }^{\circ} \mathrm{C}$ and $25^{\circ} \mathrm{C}$ during 3 months of storage. Furthermore, due to the inherent mucoadhesiveness of chitosan, NLs formulated with this polymer exhibit increased affinity for mucin $(68 \%)$, the major mucus component, when compared to NLs prepared without chitosan, as revealed in a mucin adsorption model [143]. These results were corroborated by chitosan-coated NLs possessing increased mucus affinity synthetized by Filipović-Grcić et al. [144] and Andersen et al. [145].

Liposomal quercetin encapsulation $\left(0.02 \mathrm{mg} \cdot \mathrm{mL}^{-1}\right)$ in rice bran phospholipids $\left(0.13 \mathrm{mg} \cdot \mathrm{mL}^{-1}\right)$ by the thin film-sonication method yielded spherical $157.33 \mathrm{~nm}$ NLs with an $84.9 \%$ encapsulation efficiency. The NLs were stable at $4{ }^{\circ} \mathrm{C}$ and $27^{\circ} \mathrm{C}$ for five months as indicated by the unchanged DPPH radical-scavenging assays and high quercetin NL 
retention (>97\%). In addition, NLs displayed limited gastric degradation with a sustained release of $20 \%$ of quercetin after $4 \mathrm{~h}$ in gastric fluid, followed by a sustained intestinal release of $70 \%$ up to $24 \mathrm{~h}$ [146].

The nano-encapsulation of a mixture of bioactive substances in the same particle can be a good strategy for oral antioxidant co-supplementation with greater physicochemical potential and biological property retention [147]. Chen et al. [128] co-loaded quercetin and EGCG into NLs formulated under optimal conditions (lecithin-total polyphenol ratio of 25:1, lecithin-cholesterol ratio of 6:1, lecithin-Tween 80 ratio of 8:1, and ultrasonic time of $2 \mathrm{~min}$ ). The mean size, PDI and zeta potential of these NLs were $111.10 \mathrm{~nm}, 0.259$, and $-19.83 \mathrm{mV}$, with an encapsulation efficiency of $61.7 \%$ and $64 \%$ for quercetin and EGCG, respectively. The NLs displayed a $4 \%$ size increase after 30 days at $4{ }^{\circ} \mathrm{C}$, but no significant change in PDI and the zeta potential. The co-encapsulation of these polyphenols promoted a synergistic antioxidant effect evaluated against radical DPPH (IC50 $21.7 \mathrm{mg} \cdot \mathrm{L}^{-1}$ ), as evidenced by the $\gamma$ value (0.91) [128].

This evidence indicates that nanoliposomes represent a promising tool for polyphenol delivery.

\section{Nano-Encapsulated Polyphenols Bioaccessibility and Bioavailability}

Polyphenols display antioxidant and anti-inflammatory effects that play a preventive and therapeutic role in chronic diseases such as cardiovascular and neurodegenerative conditions, as well as neoplasms [148]. To be effective in the human body, polyphenols must be available and present in pharmacological concentrations to target organs or tissues after intestinal absorption. When ingested, polyphenols that comprise part of food matrices suffer a series of chemical modifications, being hydrolyzed and conjugated by methylation, alkylation, sulfation, and glucuronidation reactions in the small intestine and liver during absorption and before reaching the systemic circulation. The remaining compounds reach the large intestine and colon, where they may undergo further metabolization by the microbiome to generate other functional compounds or be excreted in the feces and urine [149]. Conversely, the interaction of polyphenols with food matrix constituents, such as proteins, fibers, and minerals can negatively impact their bioaccessibility and oral bioavailability [150-154].

As mentioned previously, the technological functionalities of NPs regarding polyphenols solubility, release kinetics, and chemical structure protection when exposed to different physicochemical conditions are well recognized. However, in vitro assays should also be performed to address the stability of nano-encapsulated phenolics under unfriendly gastrointestinal conditions. The oral bioavailability of nano-encapsulated phenolics must be evaluated in pre-clinical and clinical assays to reinforce and prove the advantage of nanoencapsulation concerning bioaccessibility and bioavailability gains, since they represent restrictions toward the effectiveness of polyphenols as supplements for well-being or as an adjuvant therapy to treat chronic diseases. Several reports regarding phenolic compound gastrointestinal stability, longer residence times, and increased oral bioavailability after nano-encapsulation, with no cell or tissue damage, are available in the literature.

The trans-resveratrol-loaded into lipid core polymeric nano-capsules formed by poly( $\varepsilon$-caprolactone) and capric/caprylic-triglycerides allowed for increased accumulation of this antioxidant in the liver, kidney, and brain tissues of healthy rats compared to those supplemented with free resveratrol following intraperitoneal or gavage administration of $5 \mathrm{mg} \cdot \mathrm{kg}^{-1}$ for 14 days. The trans-resveratrol treatment may have provoked the development of gastrointestinal injuries due to inhibition of cyclooxygenase-1, while animals treated with trans-resveratrol nano-capsules exhibited lower lesion rates in the duodenum, jejunum, and ileum compared with free-resveratrol intake. It seems that an improvement in the safety usage of this antioxidant regarding gastrointestinal trait preservation can be achieved when this antioxidant is included in NPs [125].

Peanut oil and soy lecithin (oil in water) were used to encapsulate resveratrol and evaluate a simulated gastric and intestinal digestion, which resulted in resistance indicating 
that NEs allow full resveratrol availability for intestinal absorption. The size of the NEs of $250 \mathrm{~nm}$ enabled them to cross Caco-2 cell membranes and exert their intracellular antioxidant activity against hydrogen peroxide [126].

The same simulated gastrointestinal fluid resistance is noted for casein-NPs. Resveratrol-casein-NPs exhibit a 10-fold higher resveratrol bioavailability and displayed stable plasma levels for $8 \mathrm{~h}$ after a single $15 \mathrm{mg} \cdot \mathrm{kg}^{-1}$ oral administration in Wistar rats compared with a $4 \mathrm{~h}$ plasma level maintenance observed for free resveratrol. A good correlation between in vitro bioaccessibility and the resveratrol fraction absorbed in vivo $\left(R^{2}=0.99\right)$ indicates that NPs are able to carry the resveratrol to the intestinal epithelium and promote a higher absorption rate of this polyphenol [71].

Casein-hydroxypropyl- $\beta$-cyclodextrin NPs loaded with quercetin have been reported as resistant to gastrointestinal $\mathrm{pH}$ conditions and allow for the controlled release of $20 \%$ of quercetin in gastric fluid ( $\mathrm{pH}$ 1.2), and $60 \%$ after $4 \mathrm{~h}$ in intestinal fluid ( $\mathrm{pH}$ 6.8), while free quercetin is fully released when reaching gastric conditions. In rats, the plasma levels of nano-encapsulated polyphenols were prolonged for $72 \mathrm{~h}$ and $37 \%$ of bioavailability was reported after the oral ingestion of $25 \mathrm{mg} \cdot \mathrm{kg}^{-1}$, as demonstrated by a higher plasma halflife, mean residence time, and area under the curve (AUC), while free quercetin resulted in elevated plasma levels for only $8 \mathrm{~h}$ with a $4 \%$ bioavailability [155].

Ex vivo passive paracellular and transcellular transport models indicate that chitosanTPP NPs enhance polyphenol absorption and transport across excised mouse jejunum in Ussing chambers. Catechin $\left(3.6 \mathrm{mg} \cdot \mathrm{mL}^{-1}\right)$ and epigallocatechin $\left(6.2 \mathrm{mg} \cdot \mathrm{mL}^{-1}\right)$ in the NPs were significantly better transported through jejunum tissue compared to nonencapsulated polyphenols ( $302.1 \mathrm{vs} 206.8 \mathrm{ng} \cdot \mathrm{cm}^{-2}$ and $102.7 \mathrm{vs} 57.9 \mathrm{ng} \cdot \mathrm{cm}^{-2}$, respectively). This bioavailability improvement was attributed to the stability afforded by NPs, resulting in higher available polyphenol concentrations to flux across the tissue [113].

In a pharmacokinetic assay, a single $100 \mathrm{mg} \cdot \mathrm{kg}^{-1}$ dose of chlorogenic acid entrapped in chitosan-TPP NPs $(210 \mathrm{~nm})$ was administered to Wistar rats, leading to a longer polyphenol residence time in plasma, extended time to reach maximum plasma concentration, and a greater area under the curve $(p>0.01)$, configuring a slow and prolonged chlorogenic acid release in plasma and superior oral bioavailability [105].

In another study, Wistar rats received an oral supplementation of $50 \mathrm{mg} \cdot \mathrm{kg}^{-1}$ of resveratrol encapsulated in carboxymethyl-chitosan NPs. The resveratrol-NPs offered in a single dose with an absorption time of $1.76 \mathrm{~h}$, reaching a plasma peak after $6.83 \mathrm{~h}$, and excreted in $20.5 \mathrm{~h}$, while free resveratrol was rapidly absorbed at $1.12 \mathrm{~h}$, with a plasma peak at $3.21 \mathrm{~h}$, and excretion at $5.44 \mathrm{~h}$. Resveratrol nano-encapsulation in carboxymethyl-chitosan NPs thus ensured a longer permanence of the antioxidant in the systemic environment, resulting in a substantial 3.5-fold increase in bioavailability [110].

Distearoyl phosphatidyl choline and cholesterol liposomal formulations were used to load resveratrol $(10 \mathrm{mg})$, improving gastrointestinal resistance against destabilization by bile salt and sodium taurocholate solutions. In addition, rats supplemented by resveratrolNLs at $50 \mathrm{mg} \cdot \mathrm{kg}^{-1}$ exhibited sustainable resveratrol release in plasma with a two-fold increased bioavailability and a maximum plasma resveratrol concentration of $0.42 \mu \mathrm{g} \cdot \mathrm{mL}^{-1}$ and AUC $1.44 \mu \mathrm{g} \cdot \mathrm{h} \cdot \mathrm{mL}^{-1}$ after $6 \mathrm{~h}$, while free resveratrol was found at $0.33 \mu \mathrm{g} \cdot \mathrm{mL}^{-1}$ at $30 \mathrm{~min}$ with an AUC of $0.633 \mu \mathrm{g} \cdot \mathrm{h} \cdot \mathrm{mL}^{-1}$. In the same assay, nano-encapsulated resveratrol was found to be predominantly absorbed as the unmetabolized chemical structure (RSV-3-O-glucuronide), while free-resveratrol intake generated higher plasmatic metabolite levels [156], corroborating greater stability and bioavailability conferred by NLs.

In short, poor polyphenol bioaccessibility and bioavailability can be overcome by their encapsulation in NPs or NEs obtained from natural food-grade polymers. Such benefits are the result of the chemical protection and enhanced solubility conferred by the polymeric matrices involving polyphenols, guaranteeing a greater number of intact polyphenol molecules able to reach absorption sites. In addition, the nanometric size of the particles, cell adhesion, and permeation properties facilitate polyphenol diffusion through membranes, increasing their absorption through the intestinal epithelium and ensuring bioavailability. 
Finally, the residence time of NPs containing polyphenols in biological compartments also increases their bioactive performance.

\section{Critical Analysis of the Effectiveness of Nano-Encapsulated Polyphenols on Cardiovascular Performance: Pre-Clinical and Clinical Trials}

The protective role that polyphenols play in pathophysiological disorders that lead to endothelial dysfunctions and cardiovascular events is strongly supported by scientific evidence. Polyphenols are pleiotropic compounds that exert epigenetic, antioxidant, and antiinflammatory effects on various tissues, including vascular and cardiac tissues [157-160]. In humans, the regular intake of polyphenols such as curcumin, catechin, quercetin, anthocyanins, and resveratrol, attenuate hypertension, hyperglycemia, hyperlipidemias, oxidative stress and overall inflammatory status, which are the major physiological conditions able to trigger cardiovascular events [8-10,22,160,161].

However, attempts to demonstrate the effect of isolated antioxidant molecules following oral intake on antioxidant status, lipid peroxidation, and inflammatory markers in humans have failed, perhaps due to the chemical instability of these molecules along the gastrointestinal trait alongside their low bioavailability in biological fluids [162-165].

In general, clinical trials designed to evaluate the effects of polyphenol-loaded NPs on cardiovascular performance are scarce. Boarescu et al. [166-168] approached this knowledge gap by evaluating the effects of curcumin nano-encapsulated on cardiac tissue in animal model, reporting that curcumin-NPs protect against damage to cardiomyocytes, acute myocardial infarction, and post-infarction cardiac injury induced by isoprenol in healthy and diabetic rats. The effects of NPs at $200 \mathrm{mg} \cdot \mathrm{kg}^{-1}$ were superior to non-encapsulated curcumin and governed by inherent NP properties, which increase polyphenol bioavailability and delivery to the infarcted area, while also affecting pro-inflammatory cytokines and oxidative stress, as expected for curcumin, albeit enhanced by nano-encapsulation [169]. In addition, electrocardiograms and blood pressure tests have reinforced the beneficial role of nano-encapsulated curcumin on cardiac function. Although the nano-encapsulating polymer was not specified, the aforementioned measures indicate a promising therapeutic efficacy of nano-encapsulated polyphenols. Ray et al. [170] also demonstrated that curcumin loaded in carboxymethyl chitosan-NPs and offered at an oral dose of $5 \mathrm{mg} \cdot \mathrm{kg}^{-1}$ was successfully delivered to compromised myocardium, reducing cardiac hypertrophy and apoptosis in male Wistar rats.

Resveratrol-loaded zein-NPs were able to reduce serum tumor necrosis factor (TNF- $\alpha)$ levels in $15 \%$ compared to free resveratrol after the orally administration of $15 \mathrm{mg} \cdot \mathrm{kg}^{-1}$ doses for 7 days to C57BL/6J female mice [171]. As TNF- $\alpha$ is one of the most potent pro-inflammatory cytokines involved in a broad range of immune and inflammatory processes such as atherosclerosis, the cardiovascular effect of nano-encapsulated resveratrol should be considered as a cardioprotective dietary intervention [172]. The same effect was observed after the administration of quercetin-loaded in zein-2-hydroxypropyl- $\beta$ cyclodextrin NPs at $25 \mathrm{mg} \cdot \mathrm{kg}^{-1}$ for 1 week, which resulted in a significant TNF- $\alpha$ decrease when comparing animals treated with quercetin and the control group $(p<0.05$ and $p<0.01$, respectively) [173].

Anti-inflammatory effects were also demonstrated when cherry extracts (Prunus avium L.), which are rich in polyphenols (quercetin and cyanidin-3-glucoside), were encapsulated in quaternary ammonium chitosan-NPs. NPs displaying $2 \mu \mathrm{g} \cdot \mathrm{m}^{-1}$ of gallic acid equivalents (GAE) were incubated with human endothelial cells after lipopolysaccharide-induced inflammation, significantly reducing TNF- $\alpha$, interleukin-6 (IL-6), NO, and cyclooxygenase2-dependent (COX-2) prostaglandin E2 levels and increasing anti-inflammatory IL-10 [174].

Curcumin in micelle-NPs significantly reduced the mRNA expression and secretion of serum IL-1 $\beta$ and IL-6 cytokines in COVID-19 patients supplemented for 14 days with $160 \mathrm{mg}$ of NPs [175]. COVID-19 is a high-incidence disease displaying high mortality rates worldwide, characterized by the increased secretion of pro-inflammatory cytokines and acute inflammation that compromises the cardiovascular system [176]. 
As mentioned previously, polyphenols can protect macromolecules and tissues against oxidative damage due to their antioxidant properties, which can be enhanced by nanoencapsulation. Oxidative stress is a physiopathological condition enrolled in risk factors for cardiovascular diseases, and the monitoring of end products generated from the oxidation of biological macromolecules in biological fluids as well as intracellular antioxidant enzyme levels are used to assess the degree of cell damage and the therapeutic potential of drugs and bioactive compounds [177]. Oxidative stress markers such as NOx, malondialdehyde (MDA), total oxidative stress, catalase, and total antioxidant capacity, were normalized in the plasma of Wistar rats following the intake of a liposomal curcumin formulation based on dipalmitoyl-sn-glycero-3-phosphocholine, 1,2-distearoyl-snglycero-3-phosphoethanolamine-N-[amino(polyethylene glycol)-2000] (PEG-2000-DSPE), and cholesterol $\left(10\right.$ and $20 \mathrm{mg} \cdot \mathrm{kg}^{-1}$ ) for 8 days after oxidative stress development induced by gentamicin. Concerning all the evaluated oxidative damage indicators, curcumin in NLs was more effective than free curcumin supplementation [178].

Oxidized amino acids (free or protein-bound) are typical oxidative stress markers, and dityrosine bonds formed in low density lipoprotein (LDL) particles comprise atherogenesis indicators [179]. Protein oxidation and consequent cross-linked dityrosine formation are inhibited by quercetin and myricetin individually loaded in chitosan-NPs. Both polyphenols inhibited ribonuclease A oxidation and the crosslink induced by potassium persulfate $\left(\mathrm{K}_{2} \mathrm{~S}_{2} \mathrm{O}_{8}\right)$ at $25 \mu \mathrm{g} \cdot \mathrm{mL}^{-1}$ [109].

Resveratrol is known to protect the cardiovascular system by alleviating oxidative stress and controlling blood glucose [180]. Synthesized PEG-cholesterol NLs (200 nm) containing resveratrol $\left(2.5-100 \mu \mathrm{g} \cdot \mathrm{mL}^{-1}\right)$, displayed significant glycemic and insulinemic control in $\mathrm{B}$ TC cells following diabetes induced by glucose and streptozotocin. In addition, cellular oxidative stress caused by long exposure periods to glucose and streptozotocin was mitigated following $24 \mathrm{~h}$ incubation with resveratrol-NLs, which significantly restored superoxide dismutase (SOD) and glutathione peroxidase (GSH-Px) levels compared to in-solution resveratrol administration [181].

Anthocyanins, the major polyphenol pigment in plants, can also reduce physiopathological damages associated with type 2 diabetes, but with limited effects due to poor chemical stability, aqueous solubility, and bioavailability [182,183]. Anthocyanin-loaded niosomes, administered as a functional drink, may result in beneficial effects on the reversal of metabolic abnormalities associated with diabetes and obesity in mice fed a fat diet. Niosomes containing anthocyanins offered to obese and insulin-resistant mice at $160 \mu \mathrm{g} \cdot \mathrm{mL}^{-1}$ over a four-week period improved glucose tolerance and insulin sensitivity and led to a significant reduction in fasting glucose, insulin levels, and leptin. Furthermore, decreases in blood insulin levels of animals treated with anthocyanins-loaded niosomes were more effective than free-anthocyanin and as effective as metformin, demonstrating that niosomes may increase polyphenol carbohydrate metabolism effectiveness [184].

Quercetin loaded into alginate-chitosan NPs $\left(10 \mu \mathrm{g} \cdot \mathrm{mL}^{-1}\right)$ displayed protective effects against peroxidation induced by iron/ascorbic acid in isolated rat liver microsomes, as determined by significant MDA level decreases. In addition, quercetin NPs containing a higher chitosan concentration $\left(3 \mathrm{mg} \cdot \mathrm{mL}^{-1}\right)$ resulted in significant protection against $\mathrm{t}$-BuOOH-induced GSH depletion, increasing the levels of this tripeptide by $183 \%$ [77]. In short, antioxidants, especially those belonging to the polyphenol class, which represent the most abundant dietary bioactive compounds, are arguably excessive reactive oxygen and nitrogen species removers, also able to regulate endogenous defenses and attenuate inflammation, which are key processes in the progression of cardiovascular diseases when in physiological imbalance. However, food processing, environmental factors, and gastrointestinal and the systemic instability of the human body limit polyphenol bioavailability and bioactivity, compromising their oral administration effectiveness. A large number of in vitro assays, cell cultures, and animals comprising storage, digestive, pharmacokinetics, absorptive, and adverse metabolic models, have demonstrated that the application of 
nanotechnology in polyphenol encapsulation indicates their use as a therapeutic agent for humans.

The current scientific framework demonstrates that the synthesis of nano-encapsulated polyphenols loaded in food grade polymers and lipids can be physiologically safe. NPs increase environmental and digestive polyphenol stability, maintaining these molecules intact during the enteric route to intestinal absorption sites. After becoming more accessible to the intestinal epithelium, nano-encapsulated polyphenols exhibit greater mucoadhesiveness and display the ability to be taken up in greater amounts by intestinal cells, reaching systemic levels in their non-metabolized form. The high concentrations of intact nanoencapsulated polyphenols that cross the intestinal epithelium allows them to reach high systemic levels while, at the same time, be released gradually, with a longer half-life and residence time compared to non-encapsulated polyphenols. The gradual release and long permanence of polyphenols in their active form in the human body conferred by NPs thus allow for their effective use as an adjuvant therapy against cardiovascular diseases.

\section{Nanoparticles: Safety and Cytotoxicity}

The application of nanotechnology has increased substantially in science and in the materials technology, medicine, food, and agriculture fields. Several commercially available products, such as toothpaste, wound dressings, sunscreens, and skin creams contain NPs in their formulations, mostly produced using silver, zinc oxides, silica, and gold [185-187]. This represents increasing human exposure to NPs, which can be inhaled, ingested, and absorbed transdermally, stimulating biosafety questions. The safety of NPs is questioned due to their physicochemical characteristics (size, shape, charge, etc.), which makes them easier to permeate, penetrate, and be retained in cells and tissues, which may or may not be desirable, as NPs can accumulate in organs for considerably long periods of time without adequate clearance, culminating in oxidative tissue stress, inflammation, and cell death. In blood, NPs display the ability to adsorb proteins from the physiological fluid and inducing platelet aggregation, coagulation, and hemolysis [188,189]. In addition, information concerning NP behavior in the body is not fully elucidated, compromising knowledge on their harmful and beneficial effects [190]. In this sense, the European Food Safety Authority (EFSA) [191] has stablished guidelines on the physical-chemical characterization and analytical methods used in determining the systemic behavior of nanoproducts, which includes absorption, metabolism, cell-NP interaction, excretion, and toxicity mechanisms. Although this document does not represent an official regulatory guideline for nanotechnology, no other regimentations are available. Other agencies, such as the European Medicine Agency (EMA), Organization for Economic Co-operation and Development (OECD), and National Nanotechnology Initiative (NNI), have established provisional guidelines in an attempt to partially regulate nanotechnology application standards [192].

In contrast, the use of food-grade NPs, mainly in the medicine and food technology fields, represents a better solution in view of the uncertainty concerning nanoproduct safety. Food-grade polymers are biodegradable, do not generate toxic by-products, are biocompatible, non-immunogenic, and permeable to biological barriers and certain polymers display biological activities. In addition, most are classified as "substances generally recognized as safe" (GRAS) status designated by the Food and Drug Administration (FDA) [30,193]. These characteristics have stimulated the use of compounds obtained from natural sources, such as polysaccharides, proteins and lipids, as raw materials to build nano-capsules for the delivery of therapeutic agents and other nanotechnological purposes with no adverse human health effects [194]. The number of nano products based on food-grade polymers submitted to the FDA over the last two decades has increased, intended predominantly for intravenous and oral delivery. Liposomes were the first FDA-approved drug nanocarrier and are included in one of the most requested and approved nanoproduct category $(33 \%)$, followed by nanocrystals $(23 \%)$, emulsions (14\%), iron-polymer complexes $(9 \%)$, 
and micelles $(6 \%)$, while the last $14 \%$ of requests consist mainly of nanoproducts coated by polymers, or drug-protein complexes [195,196].

Currently, a number of food-grade NP coated drugs for use in medicine, such as Abraxane ${ }^{\circledR}$, Doxil ${ }^{\circledR}$, and Zinostatin/stimalmar ${ }^{\circledR}$, among others, are approved for commercialization [197]. To the best of our knowledge, curcumin-NPs, known as THERACURMIN and provided by Theravalues Corporation (Tokyo, Japan), are the only food-grade polyphenol coated with a biodegradable material commercially available as a non-drug marketed for dietary supplementation. These NPs are $190 \mathrm{~nm}$ in size and consist of $10 \%$ curcumin, $2 \%$ other curcuminoids such as demethoxycurcumin and bisdemethoxycurcumin, $46 \%$ glycerin, $4 \%$ gum ghatti, and $38 \%$ water.

Other formulations containing encapsulated curcumin in solid lipid NPs (WO/2007/103435), oil emulsion NPs (CN1736369), and chitosan NPs (WO2010013224A2) have been formulated and patented for human applications. Several studies have demonstrated that curcumin may be beneficial in different disorders, such as Alzheimer's disease, cardiovascular diseases, and psoriasis, due to its anti-inflammatory, antioxidant, and anticancer effects $[198,199]$. For this reason, curcumin has often been administered in several unhealthy conditions [200].

In vitro cytotoxicity assays are performed as part of product characterization during the formulation of NPs from natural polymers, in order to assess or rule out potential cell damage that can make their use unfeasible. Although pre-clinical and clinical trials are more appropriate, they are expensive and slower. In addition, pre-clinical trials in animal models have been discouraged due to animal sacrifice, as recommended by the European Commission, which guides the scientific community on the replacement of animal trials based on the "replacement, reduction, and refinement of animal use" principle [201].

Cultures comprising Caco-2 intestinal cells, erythrocytes, respiratory tract cells, epithelial cells, hepatocytes, and embryonic cells are of the in vitro models applied in cytotoxicity food-grade NPs coated polyphenol assays (Table 1).

Table 1. Cytotoxicity testing of food-grade NPs in healthy cultured cells.

\begin{tabular}{|c|c|c|c|c|c|c|c|}
\hline Wall Polymer & Polyphenol & $\begin{array}{l}\text { Cytotoxicity } \\
\text { Assay }\end{array}$ & $\begin{array}{l}\text { Cell } \\
\text { Culture }\end{array}$ & $\begin{array}{l}\text { Exposure } \\
\text { Time }\end{array}$ & $\begin{array}{c}\mathrm{NP} \\
\text { Concentration }\end{array}$ & $\begin{array}{c}\text { Cell } \\
\text { Viability }\end{array}$ & Reference \\
\hline $\begin{array}{l}\text { Thiolated quaternary } \\
\text { ammonium- } \\
\text { chitosan }\end{array}$ & $\begin{array}{l}\text { Grape seed } \\
\text { polyphenols }\end{array}$ & WST-1 & EPCs & $3 \mathrm{~h}$ & $\begin{array}{c}0-4.9 \\
\mu \mathrm{g} \cdot \mathrm{mL}^{-1}\end{array}$ & $100 \%$ & [202] \\
\hline $\begin{array}{c}\text { Soy protein } \\
\text { nanoemulsion }\end{array}$ & Catechins & MTT & Caco-2 & $24 \mathrm{~h}$ & $\begin{array}{l}75 \text { and } 500 \\
\mu \mathrm{g} \cdot \mathrm{mL}^{-1}\end{array}$ & 95 and $85 \%$ & [203] \\
\hline Starch NPs & $\begin{array}{l}\text { Catechin, } \\
\text { epicatechin, } \\
\text { epigallocatechin, } \\
\text { proanthocyanidin, } \\
\text { individually } \\
\text { encapsulated and } \\
\text { assayed }\end{array}$ & MTT & MEF & $24 \mathrm{~h}$ & $\begin{array}{c}0.015-0.250 \\
\mu \mathrm{g} \cdot \mathrm{mL}^{-1}\end{array}$ & $>80 \%$ & [75] \\
\hline $\begin{array}{l}\text { Transcutol-based } \\
\text { nanoemulsion }\end{array}$ & Curcumin & MTT & $\begin{array}{l}\text { nasal ep- } \\
\text { ithelium }\end{array}$ & $72 \mathrm{~h}$ & $\begin{array}{c}0.012-1 \\
\mathrm{mg} \cdot \mathrm{mL}^{-1}\end{array}$ & $100 \%$ & [127] \\
\hline $\begin{array}{c}\text { Chitosan-alginate } \\
\text { NPs }\end{array}$ & Quercetin & $\begin{array}{l}\text { MTT } \\
\text { LDH }\end{array}$ & HepG2 & $24 \mathrm{~h}$ & $10 \mu \mathrm{g} \cdot \mathrm{mL}^{-1}$ & $100 \%$ & [77] \\
\hline $\begin{array}{c}\text { Zein-casein-lysine } \\
\text { NPs }\end{array}$ & Ferulic acid & MTT & Caco-2 & $24 \mathrm{~h}$ & $\begin{array}{l}0.1-1000 \\
\mu \mathrm{g} \cdot \mathrm{mL}^{-1}\end{array}$ & $94 \%$ & [72] \\
\hline $\begin{array}{c}\text { Zein-casein-lysine } \\
\text { NPs }\end{array}$ & Ferulic acid & MTT & Caco-2 & $4 \mathrm{~h}$ & $\begin{array}{c}100 \text { and } 300 \\
\mu \mathrm{g} \cdot \mathrm{mL}^{-1}\end{array}$ & $100 \%$ & [72] \\
\hline
\end{tabular}


Table 1. Cont.

\begin{tabular}{|c|c|c|c|c|c|c|c|}
\hline Wall Polymer & Polyphenol & $\begin{array}{l}\text { Cytotoxicity } \\
\text { Assay }\end{array}$ & $\begin{array}{c}\text { Cell } \\
\text { Culture }\end{array}$ & $\begin{array}{l}\text { Exposure } \\
\text { Time }\end{array}$ & $\begin{array}{c}\mathrm{NP} \\
\text { Concentration }\end{array}$ & $\begin{array}{c}\text { Cell } \\
\text { Viability }\end{array}$ & Reference \\
\hline Liposomes NPs & Resveratrol & MTT & $\begin{array}{c}\text { ß- } \\
\text { pancreatic }\end{array}$ & $24 \mathrm{~h}$ & $25 \mu \mathrm{g} \cdot \mathrm{mL}^{-1}$ & $>90 \%$ & [181] \\
\hline $\begin{array}{c}\text { Quaternary } \\
\text { ammonium chitosan } \\
\text { NPs }\end{array}$ & Cherry extract & WST-1 & HUVEC & $2 \mathrm{~h}$ & $\underset{\mathrm{GAE}}{2 \mu \mathrm{g} \cdot \mathrm{mL}^{-1}}$ & $77 \%$ & [174] \\
\hline $\begin{array}{c}\text { liposome- } \\
\text { phosphatidylcholine } \\
\text { from soybean }\end{array}$ & $\begin{array}{l}\text { Quercetin and gallic } \\
\text { acid alone and } \\
\text { co-loaded }\end{array}$ & CC8-K & $\begin{array}{l}\text { RAW } \\
264.7\end{array}$ & $24 \mathrm{~h}$ & $\begin{array}{c}1,10 \text { and } 50 \\
\mu \mathrm{g} \cdot \mathrm{mL}^{-1}\end{array}$ & $100 \%$ & [138] \\
\hline
\end{tabular}

CC8-K: Cell counting Kit-8; EPCs: Endothelial progenitor cells; GAE: Gallic acid equivalents; HaCaT: Human keratinocyte cells; HepG2: Hepatocellular carcinoma cells; HUVEC: Human umbilical vein endothelial cells; LDH: Lactate dehydrogenase; MEF: Mouse embryonic fibroblast; MTT: Thiazolyl blue tetrazolium bromide; WST-1: Water-Soluble tetrazolium salt.

Das et al. [86] reported no cytotoxicity of sodium alginate-chitosan NPs loaded with curcumin after absorption by HeLa cells. According to a test conducted by [75], starch NPs loaded with catechin, epicatechin, epicatechin-3-gallate, and proanthocyanins exhibited good compatibility and no toxicity to fibroblast embryonic cells. No cytotoxic effect was found in healthy lung cells after exposure to insulin-loaded chitosan-dextran NPs [99]. Finally, in vivo toxicological evaluations were performed after a 14-day oral administration of quercetin loaded in chitosan-alginate NPs to rats $\left(0.5 \mathrm{~mL} \cdot 100 \mathrm{~g}^{-1}\right)$ [77]. No mortality or altered animal behavior was observed. The relative mass of the liver, histological sections, liver function, and hematological parameters were not altered due to NP intake, indicating no health risks and suggesting the possibility of safe oral intake.

However, tests on healthy cells are scarce due to the emphasis placed on the effects of NPs on tumor cells in different tissues, i.e., gastrointestinal and respiratory tracts and the brain $[52,62,65,87,204]$.

Although they do not clarify the mechanisms of toxicity or cell death, the colorimetric methods thiazolyl blue tetrazolium bromide (MTT) and (3-(4,5-dimethylthiazol-2-yl)-5-(3carboxymethoxyphenyl)-2-(4-sulfophenyl)-2H-tetrazolium) (MTS) concerning mitochondrial function and lactate dehydrogenase (LDH) regarding cell membrane integrity are the most applied techniques to assess NP cytotoxicity [205]. Results obtained by in vitro tests should be interpreted cautiously, due to their limitations and the fact that NPs behavior in physiological media can be affected by several factors that may influence cytotoxicity and that are not considered by in vitro tests [206].

Despite the scarcity of clinical trials with NPs, their oral and topical use in humans is well tolerated, with no severe side effects or toxicity in administration periods ranging from 4 to 12 weeks $[31,207,208]$. Recently, two lipid-NPs vaccines prepared using an ionizable lipid, phospholipid, cholesterol PEGylated lipid and distearoylphosphatidylcholine, namely BNT162b2 (Pfizer) and mRNA-1273 (Moderna), were applied to over 60 thousand volunteers (>16 yo) in randomized and placebo-controlled clinical trials concerning their safety and effectiveness against severe acute respiratory syndrome coronavirus 2 (SARS-CoV-2), after a two-injection regimen. These vaccines have been shown to be safe in animals and humans, with a low incidence of adverse effects in volunteers and an efficacy greater than 90\% in preventing severe COVID-19 [209-212]. This evidence reinforces the possible safety of bioactive and nano-encapsulated therapeutic agents into food-grade polymers and indicates that their beneficial roles overlap with possible harmful human health effects.

\section{Conclusions}

The biological effects of polyphenols on cardiovascular health are irrefutable, although their effectiveness in clinical trials in humans may be compromised due to the physiological variabilities among individuals that can compromise polyphenol physical-chemical 
integrity. However, the major challenge is to delivery these bioactive molecules through distinct routes i.e., oral, parenteral, or topical, to fulfill therapeutic needs. Polyphenol effectiveness depends on antioxidant characteristics, which requires that their chemical structure be preserved along the gastrointestinal tract during intestinal absorption, when in the bloodstream, when reaching the target cell these compounds, and when crossing plasmatic or intracellular membranes in order to exert their bioactivity. The incorporation of polyphenols into NPs may keep these compounds protected from hydrolytic enzymes, oxidation, and other stringent physicochemical conditions throughout the gastrointestinal and systemic pathways, and, at the same time, overcome polyphenol bioaccessibility and bioavailability. Distinct, efficient, and safe nanocarriers have been described and seem to be able to deliver polyphenols in an adequate kinetic release guaranteeing a sustained pharmacological concentration of polyphenols for several hours. Pre-clinical assays have demonstrated that nano-encapsulated polyphenols such as ferulic acid, quercetin, gallic acid, resveratrol, catechin, epicatechin, epigallocatechin, proanthocyanidin, and curcumin, as well as whole extracts from grape seeds and cherries, exhibit no toxicity to human cell lineages. The use of polyphenols in NPs should be encouraged for the incorporation and fortification of foods and beverages, in addition to their application in the manufacturing of nutraceuticals in order to conveniently assist in the prevention of and in adjuvant therapies against multifactorial and physiopathological complex conditions, such as cardiovascular diseases and other chronic health impairments.

Abbreviations: ABTS, 2,2'-azino-bis(3-ethylbenzothiazoline-6-sulfonic acid; ADMA, asymmetric dimethylarginine; AUC, area under the curve; BSA, bovine serum albumin; $\mathrm{CHC}$, chitosan chloridate; $\mathrm{CMC}$, carboxymethyl chitosan; COX, cyclooxygenase; DDAH, dimethylarginine dimethylamino hydrolase; DPPH, 2,2-diphenyl-1-picrylhydrazyl; EFSA, European Food Safety Authority; EGCG, epigallocatechin gallate; EMA, European Medicine Agency; eNOS, nitric oxide synthase; FDA, Food and Drug Administration; GRAS, generally recognized as safe; GSH-Px, glutathione peroxidase; HSA, serum albumin; IL, interleukin; $\mathrm{K}_{2} \mathrm{~S}_{2} \mathrm{O}_{8}$, potassium persulfate; $\mathrm{LDH}$, lactate dehydrogenase; LDL, low density lipoprotein; MDA, malondialdehyde; MTS, (3-(4,5-dimethylthiazol-2-yl)-5(3-carboxymethoxyphenyl)-2-(4-sulfophenyl)-2H-tetrazolium; MTT, thiazolyl blue tetrazolium bromide; $\mathrm{mV}$, millivolt; NEs, nanoemulsions; NF- $\mathrm{KB}$, factor nuclear kappa $\mathrm{B}$; NLs, nanoliposomes; NNI, National Nanotechnology Initiative; NO, nitric oxide; Nrf2-ARE, nuclear factor erythroid-2-related factor-antioxidant response element; NPs, nanoparticles; OECD, Organization for Economic Co-operation and Development; PEG, Polyethylene glycol; PDI, polydispersity index; PPAR- $\gamma$, peroxisome proliferator-activated gamma receptor; ROS, reactive oxygen species; SOD, superoxide dismutase; TNF- $\alpha$, tumor necrosis factor; TPP, sodium tripolyphosphate; UV, ultraviolet.

Author Contributions: L.R.T., D.V.T.d.S., D.d.S.B. and V.M.F.P. conceptualized and designed the manuscript, participating in drafting the article and interpretation of data. L.R.T. and D.V.T.d.S. prepared the figures and tables. L.R.T., D.V.T.d.S., D.d.S.B. and V.M.F.P. wrote, edited, and revised the manuscript critically. V.M.F.P. revised the final written manuscript. All authors critically revised the manuscript concerning intellectual content and approved the final manuscript. All authors have read and agreed to the published version of the manuscript.

Funding: The authors are thankful for the financial support provided by the Fundação de Amparo à Pesquisa do Estado do Rio de Janeiro (FAPERJ) Brazil-grant numbers E-26/203.039/2015, E-26/203.049/2017, E-26/210.865/2018, and E-26/010.000.984/2019, PDR-10—grant no. E-26/202.254/2018 and E-26/202.345/2019, the Conselho Nacional de Desenvolvimento Científico e Tecnológico (CNPq)grant number 311422/2016-0, and the Coordenação de Aperfeiçoamento de Pessoal de Nível Superior (CAPES) Brazil-Finance Code 001, grant no. 1627392.

Institutional Review Board Statement: Not applicable.

Informed Consent Statement: Not applicable.

Conflicts of Interest: The authors declare no conflict of interest. 


\section{References}

1. Mortensen, A. Carotenoids and other pigments as natural colorants. Pure Appl. Chem. 2006, 78, 1477-1491. [CrossRef]

2. Huang, R.; $\mathrm{Xu}, \mathrm{C}$. An overview of the perception and mitigation of astringency associated with phenolic compounds. Compr. Rev. Food. Sci. Food Saf. 2020, 20, 1036-1074. [CrossRef] [PubMed]

3. Soto-Vaca, A.; Gutierrez, A.; Losso, J.N.; Xu, Z.; Finley, J.W. Evolution of phenolic compounds from color and flavor problems to health benefits. J. Agric. Food. Chem. 2012, 60, 6658-6677. [CrossRef] [PubMed]

4. Silva, D.V.T.; Baião, D.S.; Silva, F.O.; Alves, G.; Perrone, D.; Del Aguila, E.M.; Paschoalin, V.M.F. Betanin, a natural food additive: Stability, bioavailability, antioxidant and preservative ability assessments. Molecules 2019, 24, 458. [CrossRef]

5. Baião, D.D.S.; de Freitas, C.S.; Gomes, L.P.; da Silva, D.; Correa, A.C.N.T.F.; Pereira, P.R.; Aguila, E.M.D.; Paschoalin, V.M.F. Polyphenols from Root, Tubercles and Grains Cropped in Brazil: Chemical and Nutritional Characterization and Their Effects on Human Health and Diseases. Nutrients 2017, 9, 1044. [CrossRef]

6. Marx, W.; Kelly, J.; Marshall, S.; Nakos, S.; Campbell, K.; Itsiopoulos, C. The effect of polyphenol-rich interventions on cardiovascular risk factors in haemodialysis: A systematic review and meta-analysis. Nutrients 2017, 9, 1345. [CrossRef]

7. Koch, W. Dietary Polyphenols-Important Non-Nutrients in the Prevention of Chronic Noncommunicable Diseases. A Systematic Review. Nutrients 2019, 11, 1039. [CrossRef]

8. Panahi, Y.; Hosseini, M.S.; Khalili, N.; Naimi, E.; Majeed, M.; Sahebkar, A. Antioxidant and anti-inflammatory effects of curcuminoid-piperine combination in subjects with metabolic syndrome: A randomized controlled trial and an updated metaanalysis. Clin. Nutr. 2015, 34, 1101-1108. [CrossRef] [PubMed]

9. Hoseini, A.; Namazi, G.; Farrokhian, A.; Reiner, Ž.; Aghadavod, E.; Bahmani, F.; Asemi, Z. The effects of resveratrol on metabolic status in patients with type 2 diabetes mellitus and coronary heart disease. Food Funct. 2019, 10, 6042-6051. [CrossRef] [PubMed]

10. Brüll, V.; Burak, C.; Stoffel-Wagner, B.; Wolffram, S.; Nickenig, G.; Müller, C.; Langguth, P.; Alteheld, B.; Fimmers, R.; Naaf, S.; et al. Effects of a quercetin-rich onion skin extract on $24 \mathrm{~h}$ ambulatory blood pressure and endothelial function in overweight-to-obese patients with (pre-)hypertension: A randomized double-blinded placebo-controlled cross-over trial. Br. J. Nutr. 2015, 114, 1263-1277. [CrossRef] [PubMed]

11. Chekalina, N.I. Resveratrol has a positive effect on parameters of central hemodynamics and myocardial ischemia in patients with stable coronary heart disease. Wiad Lek. 2017, 70, 286-291. [PubMed]

12. Liu, Y.J.; Zhan, J.; Liu, X.L.; Wang, Y.; Ji, J.; He, Q.Q. Dietary flavonoids intake and risk of type 2 diabetes: A meta-analysis of prospective cohort studies. Clin. Nutr. 2014, 33, 59-63. [CrossRef] [PubMed]

13. Guo, X.; Yang, B.; Tan, J.; Jiang, J.; Li, D. Associations of dietary intakes of anthocyanins and berry fruits with risk of type 2 diabetes mellitus: A systematic review and meta-analysis of prospective cohort studies. Eur. J. Clin. Nutr. 2016, 70, 1360-1367. [CrossRef] [PubMed]

14. Huang, J.; Qin, S.; Huang, L.; Tang, Y.; Ren, H.; Hu, H. Efficacy and safety of Rhizoma curcumea longae with respect to improving the glucose metabolism of patients at risk for cardiovascular disease: A meta-analysis of randomised controlled trials. J. Hum. Nutr. Diet. 2019, 32, 591-606. [CrossRef]

15. Asgary, S.; Karimi, R.; Momtaz, S.; Naseri, R.; Farzaei, M.H. Effect of resveratrol on metabolic syndrome components: A systematic review and meta-analysis. Rev. Endocr. Metab. Disord. 2019, 20, 173-186. [CrossRef] [PubMed]

16. Li, H.; Xia, N.; Hasselwander, S.; Daiber, A. Resveratrol and vascular function. Int. J. Mol. Sci. 2019, 20, 2155. [CrossRef]

17. Appeldoorn, M.M.; Venema, D.P.; Peters, T.H.; Koenen, M.E.; Arts, I.C.; Vincken, J.P.; Gruppen, H.; Keijer, J.; Hollman, P.C. Some phenolic compounds increase the nitric oxide level in endothelial cells in vitro. J. Agric. Food. Chem. 2009, 57, 7693-7699. [CrossRef]

18. Li, P.G.; Sun, L.; Han, X.; Ling, S.; Gan, W.T.; Xu, J.W. Quercetin induces rapid eNOS phosphorylation and vasodilation by an Akt-independent and PKA-dependent mechanism. Pharmacology 2012, 89, 220-228. [CrossRef] [PubMed]

19. Tang, W.J.; Hu, C.P.; Chen, M.F.; Deng, P.Y.; Li, Y.J. Epigallocatechin gallate preserves endothelial function by reducing the endogenous nitric oxide synthase inhibitor level. Can. J. Physiol. Pharmacol. 2006, 84, 163-171. [CrossRef]

20. Frombaum, M.; Therond, P.; Djelidi, R.; Beaudeux, J.L.; Bonnefont-Rousselot, D.; Borderie, D. Piceatannol is more effective than resveratrol in restoring endothelial cell dimethylarginine dimethylaminohydrolase expression and activity after high-glucose oxidative stress. Free. Radic. Res. 2011, 45, 293-302. [CrossRef]

21. Zhou, Y.; Jiang, Z.; Lu, H.; Xu, Z.; Tong, R.; Shi, J.; Jia, G. Recent advances of natural polyphenols activators for keap1-nrf2 signaling pathway. Chem. Biodivers. 2019, 16, 1900400. [CrossRef] [PubMed]

22. Hussain, T.; Tan, B.; Yin, Y.; Blachier, F.; Tossou, M.C.B.; Rahu, N. Oxidative stress and inflammation: What polyphenols can do for us? Oxid. Med. Cell. Longev. 2016, 2016, 9. [CrossRef] [PubMed]

23. Rock, W.; Rosenblat, M.; Miller-Lotan, R.; Levy, A.P.; Elias, M.; Aviram, M. Consumption of wonderful variety pomegranate juice and extract by diabetic patients increases paraoxonase 1 association with high-density lipoprotein and stimulates its catalytic activities. J. Agric. Food. Chem. 2008, 56, 8704-8713. [CrossRef] [PubMed]

24. Zhu, Y.; Huang, X.; Zhang, Y.; Wang, Y.; Liu, Y.; Sun, R.; Xia, M. Anthocyanin supplementation improves HDL-associated paraoxonase 1 activity and enhances cholesterol efflux capacity in subjects with hypercholesterolemia. J. Clin. Endocrinol. Metab. 2014, 99, 561-569. [CrossRef] 
25. Scazzocchio, B.; Vari, R.; Filesi, C.; D’Archivio, M.; Santangelo, C.; Giovannini, C.; Iacovelli, A.; Silecchia, G.; Li Volti, G.; Galvano, F.; et al. Cyanidin-3-O- $\beta$-glucoside and protocatechuic acid exert insulin-like effects by upregulating PPAR gamma activity in human omental adipocytes. Diabetes 2011, 60, 2234-2244. [CrossRef]

26. Kang, G.G.; Francis, N.; Hill, R.; Waters, D.; Blanchard, C.; Santhakumar, A.B. Dietary polyphenols and gene expression in molecular pathways associated with type 2 diabetes mellitus: A review. Int. J. Mol. Sci. 2019, 21, 140. [CrossRef]

27. Bravo, L. Polyphenols: Chemistry, dietary sources, metabolism, and nutritional significance. Nutr. Rev. 1998, 56, 317-333. [CrossRef]

28. Rubió, L.; Macià, A.; Motilva, M.J. Impact of various factors on pharmacokinetics of bioactive polyphenols: An overview. Curr. Drug. Metab. 2014, 15, 62-76. [CrossRef]

29. Bilia, A.R.; Piazzini, V.; Guccione, C.; Risaliti, L.; Asprea, M.; Capecchi, G.; Bergonzi, M.C. Improving on nature: The role of nanomedicine in the development of clinical natural drugs. Planta Med. 2017, 83, 366-381. [CrossRef]

30. Bilia, A.R.; Piazzini, V.; Risaliti, L.; Vanti, G.; Casamonti, M.; Wang, M.; Bergonzi, M.C. Nanocarriers: A successful tool to increase solubility, stability and optimise bioefficacy of natural constituents. Curr. Med. Chem. 2018, 25, 1-24. [CrossRef] [PubMed]

31. Bilia, A.R.; Bergonzi, M.C.; Isacchi, B.; Antiga, E.; Caproni, M. Curcumin nanoparticles potentiate therapeutic effectiveness of acitrein in moderate-to-severe psoriasis patients and control serum cholesterol levels. J. Pharm. Pharmacol. 2018, 70, 919-928. [CrossRef] [PubMed]

32. Suganya, V.; Anuradha, V. Microencapsulation and nano-encapsulation: A review. Int. J. Pharm. Clin. Res. 2017, 9, 233-239. [CrossRef]

33. Erdoğar, N.; Akkın, S.; Bilensoy, E. Nano-capsules for Drug Delivery: An Updated Review of the Last Decade. Recent Pat Drug Deliv. Formul. 2018, 12, 252-266. [CrossRef] [PubMed]

34. Bowman, K.; Leong, K.W. Chitosan nanoparticles for oral drug and gene delivery. Int. J. Nanomed. 2006, 1, 117-128. [CrossRef] [PubMed]

35. Gouin, S. Microencapsulation: Industrial appraisal of existing technologies and trends. Trends. Food. Sci. Tech. 2004, 15, 330-347. [CrossRef]

36. Ezhilarasi, P.N.; Karthik, P.; Chhanwal, N.; Anandharamakrishnan, C. Nano-encapsulation techniques for food bioactive components: A review. Food Bioprocess. Technol. 2013, 6, 628-647. [CrossRef]

37. Gupta, R.; Badhe, Y.; Mitragotri, S.; Rai, B. Permeation of nanoparticles across the intestinal lipid membrane: Dependence on shape and surface chemistry studied through molecular simulations. Nanoscale 2020, 12, 6318-6333. [CrossRef] [PubMed]

38. Bazana, M.T.; Codevilla, C.F.; da Silva, C.D.B.; Menezes, C.R. Nano-encapsulação de licopeno em alimentos. Ciência Nat. 2015, 37, 38-48. [CrossRef]

39. Kreuter, J. Nanoparticle-based dmg delivery systems. J. Control. Release 1991, 16, 169-176. [CrossRef]

40. Teleanu, D.M.; Chircov, C.; Grumezescu, A.M.; Volceanov, A.; Teleanu, R.I. Blood-brain delivery methods using nanotechnology. Pharmaceutics 2018, 10, 269. [CrossRef] [PubMed]

41. Hussain, N.; Jaitley, V.; Florence, A.T. Recent advances in the understanding of uptake of microparticulates across the gastrointestinal lymphatics. Adv. Drug. Deliv. Rev. 2001, 50, 107-142. [CrossRef]

42. des Rieux, A.; Fievez, V.; Garinot, M.; Schneider, Y.J.; Préat, V. Nanoparticles as potential oral delivery systems of proteins and vaccines: A mechanistic approach. J. Control. Release 2006, 116, 1-27. [CrossRef]

43. Bajpai, V.K.; Kamle, M.; Shukla, S.; Mahato, D.K.; Chandra, P.; Hwang, S.K.; Kumar, P.; Huh, Y.S.; Han, Y.K. Prospects of using nanotechnology for food preservation, safety, and security. J. Food Drug. Anal. 2018, 26, 1201-1214. [CrossRef]

44. Morris, A.L.; Mohiuddin, S.S. Biochemistry, Nutrients. In StatPearls [Internet]; StatPearls Publishing: Treasure Island, FL, USA, 2021. Available online: https:/ / www.ncbi.nlm.nih.gov/books/NBK554545 (accessed on 5 May 2021).

45. Xing, F.; Cheng, G.; Yi, K.; Ma, L. Nano-encapsulation of capsaicin by complex coacervation of gelatin, acacia, and tannins. J. Appl. Polym. Sci. 2005, 96, 2225-2229. [CrossRef]

46. Lv, Y.; Yang, F.; Li, X.; Zhang, X.; Abbas, S. Formation of heat-resistant nano-capsules of jasmine essential oil via gelatin/gum arabic based complex coacervation. Food Hydrocoll. 2013, 35, 305-314. [CrossRef]

47. Devi, N.; Sarmah, M.; Khatun, B.; Maji, T. Encapsulation of active ingredients in complex polysaccharide-protein coacervates. Adv. Colloid. And. Interface Sci. 2017, 239, 136-145. [CrossRef] [PubMed]

48. Gómez-Mascaraque, L.G.; Llavata-Cabrero, B.; Martínez-Sanz, M.; Fabra, M.J.; López-Rubio, A. Self-assembled gelatin-ıcarrageenan encapsulation structures for intestinal-targeted release applications. J. Colloid. Interface Sci. 2018, 517, 113-123. [CrossRef]

49. Wong, B.T.; Day, L.; Augustin, M.A. Deamidated wheat protein-dextran Maillard conjugates: Effect of size and location of polysaccharide conjugated on steric stabilization of emulsions at acidic pH. Food Hydrocol. 2011, 25, 1424-1432. [CrossRef]

50. Chen, Y.C.; Yu, S.H.; Tsai, G.J.; Tang, D.W.; Mi, F.L.; Peng, Y.P. Novel technology for the preparation of self-assembled catechin/gelatin nanoparticles and their characterization. J. Agric. Food. Chem. 2010, 58, 6728-6734. [CrossRef]

51. Queiroz-Reyes, C.; Ronquillo-de Jesús, E.; Duran-Caballero, N.; Aguilar-Méndez, M. Development and characterization of gelatin nanoparticles loaded with a cocoa-derived polyphenolic extract. Fruits 2014, 69, 481-489. [CrossRef]

52. Karthikeyan, S.; Prasad, N.R.; Ganamani, A.; Balamurugan, E. Anticancer activity of resveratrol-loaded gelatin nanoparticles on NCI-H460 non-small cell lung cancer cells. Biomed. Prev. Nutr. 2013, 3, 64-73. [CrossRef] 
53. Song, X.; Gan, K.; Qin, S.; Chen, L.; Liu, X.; Chen, T.; Liu, H. Preparation and characterization of general-purpose gelatin-based co-loading flavonoids nano-core structure. Sci. Rep. 2019, 9, 6365. [CrossRef] [PubMed]

54. Tao, C.; Chuah, Y.J.; Xu, C.; Wang, D.A. Albumin conjugates and assemblies as versatile bio-functional additives and carriers for biomedical applications. J. Mater. Chem. B. 2019, 7, 357-367. [CrossRef] [PubMed]

55. Caraceni, P.; Tufoni, M.; Bonavita, M.E. Clinical use of albumin. Blood Transfus. 2013, 11, 18-25. [CrossRef]

56. Wang, Y.; Wang, S.; Huang, M. Structure and enzymatic activities of human serum albumin. Curr. Pharm. Des. 2015, 21, 1831-1836. [CrossRef]

57. Kim, B.; Seo, B.; Park, S.; Lee, C.; Kim, J.O.; Oh, K.T.; Lee, E.S.; Choi, H.G.; Youn, Y.S. Albumin nanoparticles with synergistic antitumor efficacy against metastatic lung cancers. Colloids Surf. B Biointerfaces 2017, 158, 157-166. [CrossRef] [PubMed]

58. Dadparvar, M.; Wagner, S.; Wien, S.; Worek, F.H.; Von Briesen, H.; Kreuter, J. Freeze-drying of HI-6-loaded recombinant human serum albumin nanoparticles for improved storage stability. Eur. J. Pharm. Biopharm. 2014, 88, 510-517. [CrossRef]

59. Nosrati, H.; Salehiabar, M.; Manjili, H.K.; Danafar, H.; Davaran, S. Preparation of magnetic albumin nanoparticles via a simple and one-pot desolvation and co-precipitation method for medical and pharmaceutical applications. Int. J. Biol. Macromol. 2018, 108, 909-915. [CrossRef]

60. Pedrozo, R.C.; Antonio, E.; Khalil, N.M.; Mainardes, R.M. Bovine serum albumin-based nanoparticles containing the flavonoid rutin produced by nano spray drying. Braz. J. Pharm. Sci. 2020, 56, 2020. [CrossRef]

61. Antônio, E.; Khalil, N.M.; Mainardes, R.M. Bovine Serum albumin nanoparticles containing quercetin: Characterization and antioxidant activity. J. Nanosci. Nanotechnol. 2016, 16, 1346-1353. [CrossRef] [PubMed]

62. Aljabali, A.A.A.; Bakshi, H.A.; Hakkim, F.L.; Haggag, Y.A.; Al-Batanyeh, K.M.; Al Zoubi, M.S.; Al-Trad, B.; Nasef, M.M.; Satija, S.; Mehta, M.; et al. Albumin nano-encapsulation of piceatannol enhances its anticancer potential in colon cancer via downregulation of nuclear p65 and HIF-1 $\alpha$. Cancers 2020, 12, 113. [CrossRef]

63. Yassa, N.W.; Khalil, S.; Saleh, S.R.; Ghareeb, D.A.; El Demellawy, M.A.; El-Sayed, M.M. Ipriflavone and Ipriflavone loaded albumin nanoparticles reverse lipopolysaccharide induced neuroinflammation in rats. PLoS ONE 2020, 15, e0237929. [CrossRef] [PubMed]

64. Jahanban-Esfahlan, A.; Dastmalchi, S.; Davaran, S. A simple improved desolvation method for the rapid preparation of albumin nanoparticles. Int. J. Biol. Macromol. 2016, 91, 703-709. [CrossRef]

65. Kim, T.H.; Jiang, H.H.; Youn, Y.S.; Park, C.W.; Tak, K.K.; Lee, S.; Kim, H.; Jon, S.; Chen, X.; Lee, K.C. Preparation and characterization of water-soluble albumin-bound curcumin nanoparticles with improved antitumor activity. Int. J. Pharm. 2011, 403, 285-291. [CrossRef]

66. Holt, C.; Carver, J.A.; Ecroyd, H.; Thorn, D.C. Invited review: Caseins and the casein micelle: Their biological functions, structures, and behavior in foods. J. Dairy. Sci. 2013, 96, 6127-6146. [CrossRef]

67. Dalgleish, D.G. On the structural models of bovine casein micelles-review and possible improvements. Soft Matter. 2011, 7, 2265-2272. [CrossRef]

68. Holt, C. Casein and casein micelle structures, functions and diversity in 20 species. Int. Dairy J. 2016, 60, 2-13. [CrossRef]

69. Li, M.; Fokkink, R.; Ni, Y.; Kleijn, M. Bovine beta-casein micelles as delivery systems for hydrophobic flavonoids. Food Hydrocoll. 2019, 96, 653-662. [CrossRef]

70. Pan, K.; Zhong, Q.; Baek, S.J. Enhanced dispersibility and bioactivity of curcumin by encapsulation in casein nano-capsules. J. Agric. Food. Chem. 2013, 61, 6036-6043. [CrossRef] [PubMed]

71. Peñalva, R.; Morales, J.; González-Navarro, C.J.; Larrañeta, E.; Quincoces, G.; Peñuelas, I.; Irache, J.M. Increased oral bioavailability of resveratrol by its encapsulation in casein nanoparticles. Int. J. Mol. Sci. 2018, 19, 2816. [CrossRef]

72. Heep, G.; Almeida, A.; Marcano, R.; Vieira, D.; Mainardes, R.M.; Khalil, N.M.; Sarmento, B. Zein-casein-lysine multicomposite nanoparticles are effective in modulate the intestinal permeability of ferulic acid. Int. J. Biol. Macromol. 2019, 138, $244-251$. [CrossRef] [PubMed]

73. Zheng, Y.; Xiao, L.; Yu, C.; Jin, P.; Qin, D.; Xu, Y.; Yin, J.; Liu, Z.; Du, Q. Enhanced antiarthritic efficacy by nanoparticles of (-)-epigallocatechin gallate-glucosamine-casein. J. Agric. Food. Chem. 2019, 67, 6476-6486. [CrossRef]

74. Rivera, M.C.; Pinheiro, A.C.; Bourbon, A.I.; Cerqueira, M.A.; Vicente, A.A. Hollow chitosan/alginate nano-capsules for bioactive compound delivery. Int. J. Biol. Macromol. 2015, 79, 95-102. [CrossRef]

75. Liu, C.; Ge, S.; Yang, J.; Xu, Y.; Zhao, M.; Xiong, L.; Sun, Q. Adsorption mechanism of polyphenols onto starch nanoparticles and enhanced antioxidant activity under adverse conditions. J. Funct. Foods. 2016, 26, 632-644. [CrossRef]

76. Shamekhi, F.; Tamjid, E.; Khajeh, K. Development of chitosan coated calcium-alginate nano-capsules for oral delivery of liraglutide to diabetic patients. Int. J. Biol. Macromol. 2018, 120, 460-467. [CrossRef]

77. Aluani, D.; Tzankova, V.; Kondeva-Burdina, M.; Yordanov, Y.; Nikolova, E.; Odzhakov, F.; Apostolov, A.; Markova, T.; Yoncheva, K. Evaluation of biocompatibility and antioxidant efficiency of chitosan-alginate nanoparticles loaded with quercetin. Int. J. Biol. Macromol. 2017, 103, 771-782. [CrossRef] [PubMed]

78. Lee, K.Y.; Mooney, D.J. Alginate: Properties and biomedical applications. Prog. Polym. Sci. 2012, 37, 106-126. [CrossRef]

79. Lertsutthiwong, P.; Rojsitthisak, P. Chitosan-alginate nano-capsules for encapsulation of turmeric oil. Pharmazie 2011, 66, 911-915. [CrossRef] [PubMed]

80. Schoubben, A.; Blasi, P.; Giovagnoli, S.; Rossi, C.; Ricci, M. Development of a scalable procedure for fine calcium alginate particle preparation. Chem. Eng. Sci. 2010, 160, 363-369. [CrossRef] 
81. Lertsutthiwong, P.; Rojsitthisak, P.; Nimmannit, U. Preparation of turmeric oil-loaded chitosan-alginate biopolymeric nanocapsules. Mater. Sci. Eng. C 2009, 29, 856-860. [CrossRef]

82. Balaji, R.; Raghunathan, S.; Revathy, R. Levofloxacin: Formulation and in-vitro evaluation of alginate and chitosan nanospheres. Egypt. Pharm. 2015, 14, 30-35. [CrossRef]

83. Bhunchu, S.; Muangnoi, C.; Rojsitthisak, P.; Rojsitthisak, P. Curcumin diethyl disuccinate encapsulated in chitosan/alginate nanoparticles for improvement of its in vitro citotoxicity against MDA-MB-231 human breast cancer cells. Pharmazie 2016, 71, 691-700. [CrossRef]

84. Li, P.; Dai, Y.N.; Zhang, J.P.; Wang, A.Q.; Wei, Q. Chitosan-alginate nanoparticles as a novel drug delivery system for nifedipine. Int. J. Biomed. Sci. 2008, 4, 221-228.

85. Zhang, Y.; Wei, W.; Lv, P.; Wang, L.; Ma, G. Preparation and evaluation of alginate-chitosan microspheres for oral delivery of insulin. Eur. J. Pharm. Biopharm. 2011, 77, 11-19. [CrossRef] [PubMed]

86. Das, R.K.; Kasoju, N.; Bora, U. Encapsulation of curcumin in alginate-chitosan-pluronic composite nanoparticles for delivery to cancer cells. Nanomedicine 2010, 6, 153-160. [CrossRef]

87. Saralkar, P.; Dash, A.K. Alginate nanoparticles containing curcumin and resveratrol: Preparation, characterization, and in vitro evaluation against du145 prostate cancer cell line. AAPS Pharm. Sci. Tech. 2017, 18, 2814-2823. [CrossRef] [PubMed]

88. Nalini, T.; Basha, S.K.; Sadiq, A.M.M.; Kumari, V.S.; Kaviyarasu, K. Development and characterization of alginate / chitosan nanoparticulate system for hydrophobic drug encapsulation. J. Drug. Deliv. Sci. Technol. 2019, 52, 65-72. [CrossRef]

89. Fernandes, A.; Sousa, A.; Azevedo, J.; Mateus, N.; de Freitas, V. Effect of cyclodextrins on the thermodynamic and kinetic properties of cyanidin-3-O-glucoside. Food Res. Int. 2013, 51, 748-755. [CrossRef]

90. Kittisuban, P.; Lee, B.H.; Suphantharika, M.; Hamaker, B.R. Slow glucose release property of enzyme-synthesized highly branched maltodextrins differs among starch sources. Carbohydr. Polym. 2014, 107, 182-191. [CrossRef]

91. Gidley, M.J. Factors affecting the crystalline type (A C) of native starches and model compounds: A rationalization of observed effects in terms of polymorphic structures. Carbohydr. Res. 1987, 161, 301-304. [CrossRef]

92. Singh, J.; Kaur, L.; McCarthy, O.J. Factors influencing the physico-chemical, morphological, thermal and rheological properties of some chemically modified starches for food applications-A review. Food Hydrocoll. 2007, 21, 1-22. [CrossRef]

93. Wani, I.A.; Jabeen, M.; Geelani, H.; Masoodi, F.A.; Saba, I.; Muzaffar, S. Effect of gamma irradiation on physicochemical properties of Indian Horse Chestnut (Aesculus indica Colebr.) starch. Food Hydrocoll. 2014, 35, 253-263. [CrossRef]

94. Chin, F.C.; Yazid, S.N.A.M.; Pang, S.C. Preparation and characterization of starch nanoparticles for controlled release of curcumin. Int. J. Polym. Sci. 2014, 2014. [CrossRef]

95. Farrag, Y.; Ide, W.; Montero, B.; Rico, M.; Rodríguez-Llamazares, S.; Barral, L.; Bouza, R. Preparation of starch nanoparticles loaded with quercetin using nanoprecipitation technique. Int. J. Biol. Macromol. 2018, 114, 426-433. [CrossRef] [PubMed]

96. Ahmad, M.; Gani, A. Ultrasonicated resveratrol loaded starch nano-capsules: Characterization, bioactivity and release behavior under in-vitro digestion. Carbohydr. Polym. 2021, 251, 117111. [CrossRef] [PubMed]

97. Contri, R.V.; Soares, R.M.D.; Pohlmann, A.R.; Guterres, S.S. Structural analysis of chitosan hydrogels containing polymeric nano-capsules. Mater. Sci. Eng. C Mater. Biol. Appl. 2014, 42, 234-242. [CrossRef] [PubMed]

98. Nagpal, K.; Singh, S.K.; Mishra, D.N. Chitosan nanoparticles: A promising system in novel drug delivery. Chem. Pharm. Bull. 2010, 58, 1423-1430. [CrossRef]

99. Gatti, T.H.H.; Eloy, J.O.; Ferreira, L.M.B.; da Silva, I.C.; Pavan, F.R.; Gremião, M.P.D.; Chorilli, M. Insulin-loaded polymeric mucoadhesive nanoparticles: Development, characterization and cytotoxicity evaluation. Braz. J. Pharm. 2016, 54, e17314. [CrossRef]

100. Hejjaji, E.M.A.; Smith, A.M.; Morris, G.A. Evaluation of the mucoadhesive properties of chitosan nanoparticles prepared using different chitosan to tripolyphosphate (CS:TPP) ratios. Int. J. Biol. Macromol. 2018, 120, 1610-1617. [CrossRef]

101. Zhao, L.M.; Lu, E.S.; Zhi, L.Z.; Chen, M.J.; Shi, D.; Yang, J.; Tang, Z. Preparation and application of chitosan nanoparticles and nanofibers. Braz. J. Chem. Eng. 2011, 28, 353-362. [CrossRef]

102. Deng, X.; Cao, M.; Zhang, J.; Hu, K.; Yin, Z.; Zhou, Z.; Xiao, X.; Yang, Y.; Sheng, W.; Wu, Y.; et al. Hyaluronic acid-chitosan nanoparticles for co-delivery of mir-34a and doxorubicin in therapy against triple negative breast cancer. Biomaterials 2014, 35, 4333-4344. [CrossRef] [PubMed]

103. Sreekumar, S.; Goycoolea, F.M.; Moerschbacher, B.M.; Rodriguez, G.R.R. Parameters influencing the size of chitosan-tpp nanoand microparticles. Sci. Rep. 2018, 8, 4695. [CrossRef]

104. Stoica, R.; Somoghi, R.; Ion, R.M. Preparation of chitosan-tripolyphosphate nanoparticles for the encapsulation of polyphenols extracted from rose hips. Dig. J. Nanomater. Biostructures. 2013, 8, 955-963.

105. Nallamuthu, I.; Devi, A.; Khanum, F. Chlorogenic acid loaded chitosan nanoparticles with sustained release property, retained antioxidant activity and enhanced bioavailability. Asian. J. Pharm. Sci. 2015, 10, 203-211. [CrossRef]

106. Milinčić, D.D.; Popović, D.A.; Lević, S.M.; Kostić, A.Ž.; Tešić, Ž.L.; Nedović, V.A.; Pešić, M.B. Application of Polyphenol-Loaded Nanoparticles in Food Industry. Nanomaterials 2019, 9, 1629. [CrossRef]

107. Gomes, L.; Souza, H.; Campiña, J.; Andrade, C.; Silva, A.; Gonçalves, M.; Paschoalin, V. Edible chitosan films and their nanosized counterparts exhibit antimicrobial activity and enhanced mechanical and barrier properties. Molecules 2019, 24, 127. [CrossRef] [PubMed] 
108. Grande-Tovar, C.D.; Chaves-Lopez, C.; Serio, A.; Rossi, C.; Paparella, A. Chitosan coatings enriched with essential oils: Effects on fungi involved in fruit decay and mechanisms of action. Trends. Food. Sci. Technol. 2018, 78, 61-71. [CrossRef]

109. Roy, P.; Parveen, S.; Ghosh, P.; Ghatak, K.; Dasgupta, S. Flavonoid loaded nanoparticles as an effective measure to combat oxidative stress in Ribonuclease A. Biochimie 2019, 162, 185-197. [CrossRef] [PubMed]

110. Zu, Y.; Zhang, Y.; Wang, W.; Zhao, X.; Han, X.; Wang, K.; Ge, Y. Preparation and in vitro/in vivo evaluation of resveratrol-loaded carboxymethyl chitosan nanoparticles. Drug Deliv. 2016, 23, 981-991. [CrossRef]

111. He, B.; Ge, J.; Yue, P.; Yue, X.; Fu, R.; Liang, J.; Gao, X. Loading of anthocyanins on chitosan nanoparticles influences anthocyanin degradation in gastrointestinal fluids and stability in a beverage. Food. Chem. 2017, 221, 1671-1677. [CrossRef]

112. Rosa, C.G.; Borges, C.D.; Zambiazi, R.C.; Nunes, M.R.; Benvenutti, E.V.; Luz, S.R.; D'Avila, S.F.; Rutz, J.K. Microencapsulation of gallic acid in chitosan, b-cyclodextrin and xanthan. Ind. Crops. Prod. 2013, 46, 138-146. [CrossRef]

113. Dube, A.; Nicolazzo, J.A.; Larson, I. Chitosan nanoparticles enhance the intestinal absorption of the green tea catechins (+)-catechin and (-)-epigallocatechin gallate. Eur. J. Pharm. Sci. 2010, 41, 219-225. [CrossRef] [PubMed]

114. Zou, T.; Percival, S.S.; Cheng, Q. Preparation, characterization, and induction of cell apoptosis of cocoa procyanidins-gelatinchitosan nanoparticle. Eur. J. Pharm. Biopharm. 2012, 82, 36-42. [CrossRef] [PubMed]

115. Woranuch, S.; Yoksan, R. Preparation, characterization and antioxidant property of water-soluble ferulic acid grafted chitosan. Carbohydr. Polym. 2013, 96, 495-502. [CrossRef]

116. Kumari, A.; Yadav, S.K.; Pakade, Y.B.; Singh, B.; Yadav, S.C. Development of biodegradable nanoparticle for delivery of quercetin. Colloids. Surf. B. 2010, 80, 184-192. [CrossRef] [PubMed]

117. Hu, B.; Pan, C.; Sun, Y.; Hou, Z.; Ye, H.; Zeng, X. Optimization of fabrication parameters to produce chitosan-tripolyphosphate nanoparticles for delivery of tea catechins. J. Agric. Food. Chem. 2008, 56, 7451-7458. [CrossRef]

118. Walker, R.; Decker, E.A.; McClements, D.J. Development of food-grade nanoemulsions and emulsions for delivery of omega-3 fatty acids: Opportunities and obstacles in the food industry. Food Funct. 2015, 6, 42-55. [CrossRef] [PubMed]

119. Dasgupta, N.; Ranjan, S.; Gandhi, M. Nanoemulsions in food: Market demand. Environ. Chem. Lett. 2019, 17, 1003-1009. [CrossRef]

120. Qian, C.; Decker, E.A.; Xiao, H.; McClements, D.J. Nanoemulsion delivery systems: Influence of carrier oil on $\beta$-carotene bioaccessibility. Food. Chem. 2012, 135, 1440-1447. [CrossRef]

121. Liu, Q.; Huang, H.; Chen, H.; Lin, J.; Wang, Q. Food-Grade Nanoemulsions: Preparation, Stability and Application in Encapsulation of Bioactive Compounds. Molecules 2019, 24, 4242. [CrossRef]

122. Kumar, L.; Sarkar, D. Encapsulation of bioactive compounds using nanoemulsions. Environ. Chem. Lett. 2018, 16, 59-70. [CrossRef]

123. Ozkan, G.; Kostka, T.; Esatbeyoglu, T.; Capanoglu, E. Effects of Lipid-Based Encapsulation on the Bioaccessibility and Bioavailability of Phenolic Compounds. Molecules 2020, 25, 5545. [CrossRef] [PubMed]

124. Peng, Y.; Meng, Q.; Zhou, J.; Chen, B.; Xi, J.; Long, P.; Hou, R. Nanoemulsion delivery system of tea polyphenols enhanced the bioavailability of catechins in rats. Food Chem. 2018, 242, 527-532. [CrossRef]

125. Frozza, R.L.; Bernardi, A.; Paese, K.; Hoppe, J.B.; Silva, T.; Battastini, A.M.; Pohlmann, A.R.; Guterres, S.S.; Salbego, C. Characterization of trans-resveratrol-loaded lipid-core nano-capsules and tissue distribution studies in rats. J. Biomed. Nanotechnol. 2010, 6, 694-703. [CrossRef] [PubMed]

126. Sessa, M.; Tsao, R.; Liu, R.; Ferrari, G.; Donsì, F. Evaluation of the stability and antioxidant activity of nano-encapsulated resveratrol during in vitro digestion. J. Agric. Food. Chem. 2011, 59, 12352-12360. [CrossRef]

127. Demisli, S.; Mitsou, E.; Pletsa, V.; Xenakis, A.; Papadimitriou, V. Development and Study of Nanoemulsions and NanoemulsionBased Hydrogels for the Encapsulation of Lipophilic Compounds. Nanomaterials 2020, 10, 2464. [CrossRef]

128. Chen, W.; Zou, M.; Ma, X.; Lv, R.; Ding, T.; Liu, D. Co-Encapsulation of EGCG and Quercetin in Liposomes for Optimum Antioxidant Activity. J. Food Sci. 2019, 84, 111-120. [CrossRef]

129. Taylor, T.M.; Davidson, P.M.; Bruce, B.D.; Weiss, J. Liposomal nano-capsules in food science and agriculture. Crit. Rev. Food. Sci. Nutr. 2005, 45, 587-605. [CrossRef]

130. Matos, C.; Moutinho, C.; Lobão, P. Liposomes as a model for the biological membrane: Studies on daunorubicin bilayer interaction. J. Membr. Biol. 2012, 245, 69-75. [CrossRef]

131. Shukla, S.; Haldorai, Y.; Hwang, S.K.; Bajpai, V.K.; Huh, Y.S.; Han, Y.K. Current demands for food-approved liposome nanoparticles in food and safety sector. Front. Microbiol. 2017, 8, 2398. [CrossRef]

132. Pattni, B.S.; Chupin, V.V.; Torchilin, V.P. New developments in liposomal drug delivery. Chem. Rev. 2015, 19, 10938-10966. [CrossRef] [PubMed]

133. Corrêa, A.C.N.T.F.; Pereira, P.R.; Paschoalin, V.M.F. Preparation and characterization of nanoliposomes for the entrapment of bioactive hydrophilic globular proteins. J. Vis. Exp. 2019, 150. [CrossRef] [PubMed]

134. Kaddah, S.; Khreich, N.; Kaddah, F.; Charcosset, C.; Greige-Gerges, H. Cholesterol modulates the liposome membrane fluidity and permeability for a hydrophilic molecule. Food Chem. Toxicol. 2018, 113, 40-48. [CrossRef]

135. Fidan-Yardimci, M.; Akay, S.; Sharifi, F.; Sevimli-Gur, C.; Ongen, G.; Yesil-Celiktas, O. A novel niosome formulation for encapsulation of anthocyanins and modelling intestinal transport. Food. Chem. 2019, 293, 57-65. [CrossRef] [PubMed]

136. Chen, S.; Hanning, S.; Falconer, J.; Locke, M.; Wen, J. Recent advances in non-ionic surfactant vesicles (niosomes): Fabrication, characterization, pharmaceutical and cosmetic applications. Eur. J. Pharm. Biopharm. 2019, 144, 18-39. [CrossRef] 
137. Khan, D.H.; Bashir, S.; Figueiredo, P.; Santos, H.A.; Khan, M.I.; Peltonen, L. Process optimization of ecological probe sonication technique for production of rifampicin loaded niosomes. J. Drug. Deliv. Sci. Technol. 2019, 50, 27-33. [CrossRef]

138. Giordani, B.; Basnet, P.; Mishchenko, E.; Luppi, B.; Škalko-Basnet, N. Utilizing Liposomal quercetin and gallic acid in localized treatment of vaginal candida infections. Pharmaceutics 2019, 12, 9. [CrossRef]

139. Mozafari, M.R. Bioactive entrapment and targeting using nanocarrier technologies: An introduction. In Nanocarrier Technologies: Frontiers of Nanotherapy; Mozafari, M.R., Ed.; Springer: Dordrecht, The Netherlands, 2006; pp. 1-16.

140. Aguilar-Pérez, K.M.; Avilés-Castrillo, J.I.; Medina, D.I.; Parra-Saldivar, R.; Iqbal, H.M.N. Insight into nanoliposomes as smart nanocarriers for greening the twenty-first century biomedical settings. Front. Bioeng. Biotechnol. 2020, 8, 579536. [CrossRef]

141. Peng, S.; Zou, L.; Zhou, W.; Liu, W.; Liu, C.; McClements, D.J. Encapsulation of lipophilic polyphenols into nanoliposomes using pH-driven method: Advantages and disadvantages. J. Agric. Food Chem. 2019, 67, 7506-7511. [CrossRef]

142. Cheng, C.; Peng, S.; Li, Z.; Zou, L.; Liu, W.; Liu, C. Improved bioavailability of curcumin in liposomes prepared using a pH-driven, organic solvent-free, easily scalable process. RSC. Adv. 2017, 7, 25978-25986. [CrossRef]

143. Shin, G.H.; Chung, S.K.; Kim, J.T.; Joung, H.J.; Park, H.J. Preparation of chitosan-coated nanoliposomes for improving the mucoadhesive property of curcumin using the ethanol injection method. J. Agric. Food. Chem. 2013, 61, 11119-11126. [CrossRef]

144. Filipović-Grcić, J.; Skalko-Basnet, N.; Jalsenjak, I. Mucoadhesive chitosan-coated liposomes: Characteristics and stability. J. Microencapsul. 2001, 18, 3-12. [CrossRef]

145. Andersen, T.; Bleher, S.; Eide, F.G.; Tho, I.; Mattsson, S.; Škalko-Basnet, N. Chitosan in mucoadhesive drug delivery: Focus on local vaginal therapy. Mar. Drugs. 2015, 13, 222-236. [CrossRef]

146. Rodriguez, E.B.; Almeda, R.A.; Vidallon, M.L.P.; Reyes, C.T. Enhanced bioactivity and efficient delivery of quercetin through nanoliposomal encapsulation using rice bran phospholipids. J. Sci. Food. Agric. 2019, 99, 1980-1989. [CrossRef]

147. Caddeo, C.; Nacher, A.; Vassallo, A.; Armentano, M.F.; Pons, R.; Fernàndez-Busquets, X.; Carbone, C.; Valenti, D.; Fadda, A.M.; Manconi, M. Effect of quercetin and resveratrol co-incorporated in liposomes against inflammatory/oxidative response associated with skin cancer. Int. J. Pharm. 2016, 513, 153-163. [CrossRef]

148. Potì, F.; Santi, D.; Spaggiari, G.; Zimetti, F.; Zanotti, I. Polyphenol health effects on cardiovascular and neurodegenerative disorders: A review and meta-analysis. Int. J. Mol. Sci. 2019, 20, 351. [CrossRef] [PubMed]

149. Duda-Chodak, A.; Tarko, T.; Satora, P.; Sroka, P. Interaction of dietary compounds, especially polyphenols, with the intestinal microbiota: A review. Eur. J. Nutr. 2015, 54, 325-341. [CrossRef] [PubMed]

150. Tomas, M.; Beekwilder, J.; Hall, R.D.; Simon, C.D.; Sagdic, O.; Capanoglu, E. Effect of dietary fiber (inulin) addition on phenolics and in vitro bioaccessibility of tomato sauce. Int. Food Res. J. 2018, 106, 129-135. [CrossRef] [PubMed]

151. Tew, B.Y.; Xu, X.; Wang, H.J.; Murphy, P.A.; Hendrich, S. A diet high in wheat fiber decreases the bioavailability of soybean isoflavones in a single meal fed to women. J. Nutr. 1996, 126, 871-877. [CrossRef] [PubMed]

152. Tamura, M.; Iwami, T.; Hirayama, K.; Itoh, K. High fiber diet supplemented with rice bran hemicellulose may reduce daidzein absorption in mice. Food Sci. Technol. 2009, 15, 141-146. [CrossRef]

153. Nizamova, A.; Ziyatdinova, G.; Budnikov, G. Electrogenerated bromine as a coulometric reagent for the estimation of the bioavailability of polyphenols. J. Anal. Chem. 2011, 66, 301-309. [CrossRef]

154. Kamiloglu, S.; Tomas, M.; Ozdal, T.; Capanoglu, E. Effect of food matrix on the content and bioavailability of flavonoids. Trends. Food. Sci. Technol. 2020. [CrossRef]

155. Peñalva, R.; Esparza, I.; Morales-Gracia, J.; González-Navarro, C.J.; Larrañeta, E.; Irache, J.M. Casein nanoparticles in combination with 2-hydroxypropyl- $\beta$-cyclodextrin improves the oral bioavailability of quercetin. Int. J. Pharm. 2019, 570, 118652. [CrossRef]

156. Basavaraj, S.; Betageri, G.V. Improved oral delivery of resveratrol using proliposomal formulation: Investigation of various factors contributing to prolonged absorption of unmetabolized resveratrol. Expert. Opin. Drug. Deliv. 2014, 11, 493-503. [CrossRef] [PubMed]

157. Behl, T.; Bungau, S.; Kumar, K.; Zengin, G.; Khan, F.; Kumar, A.; Kaur, R.; Venkatachalam, T.; Tit, M.D.; Vesa, C.M.; et al. Pleotropic effects of polyphenols in cardiovascular system. Biomed. Pharmacother. 2020, 130, 110714. [CrossRef] [PubMed]

158. Pan, M.H.; Lai, C.S.; Wu, J.C.; Ho, C.T. Epigenetic and disease targets by polyphenols. Curr. Pharm. Des. 2013, 19, 6156-6185. [CrossRef] [PubMed]

159. Billingsley, H.E.; Carbone, S. The antioxidant potential of the Mediterranean diet in patients at high cardiovascular risk: An in-depth review of the predimed. Nutr. Diabetes 2018, 8, 13. [CrossRef] [PubMed]

160. Venkatakrishnan, K.; Chiu, H.F.; Cheng, J.C.; Chang, Y.H.; Lu, Y.Y.; Han, Y.C.; Shen, Y.C.; Tsai, K.S.; Wang, C.K. Comparative studies on the hypolipidemic, antioxidant and hepatoprotective activities of catechin-enriched green and oolong tea in a double-blind clinical trial. Food Funct. 2018, 9, 1205-1213. [CrossRef] [PubMed]

161. Jokioja, J.; Linderborg, K.M.; Kortesniemi, M.; Nuora, A.; Heinonen, J.; Sainio, T.; Viitanen, M.; Kallio, H.; Yang, B. Anthocyaninrich extract from purple potatoes decreases postprandial glycemic response and affects inflammation markers in healthy men. Food Chem. 2020, 310, 125797. [CrossRef] [PubMed]

162. Mirhafez, S.R.; Farimani, A.R.; Gholami, A.; Hooshmand, E.; Tavallaie, S.; Nobakht, M.G.B.F. The effect of curcumin with piperine supplementation on pro-oxidant and antioxidant balance in patients with non-alcoholic fatty liver disease: A randomized, double-blind, placebo-controlled trial. Drug Metab. Pers. Ther. 2019, 34. [CrossRef] 
163. Barrera-Reyes, P.K.; Hernández-Ramírez, N.; Cortés, J.; Poquet, L.; Redeuil, K.; Rangel-Escareño, C.; Kussmann, M.; Silva-Zolezzi, I.; Tejero, M.E. Gene expression changes by high-polyphenols cocoa powder intake: A randomized crossover clinical study. Eur. J. Nutr. 2019, 58, 1887-1898. [CrossRef] [PubMed]

164. Vors, C.; Couillard, C.; Paradis, M.E.; Gigleux, I.; Marin, J.; Vohl, M.C.; Couture, P.; Lamarche, B. Supplementation with resveratrol and curcumin does not affect the inflammatory response to a high-fat meal in older adults with abdominal obesity: A randomized, placebo-controlled crossover trial. J. Nutr. 2018, 148, 379-388. [CrossRef] [PubMed]

165. Decroix, L.; Tonoli, C.; Soares, D.D.; Descat, A.; Drittij-Reijnders, M.J.; Weseler, A.R.; Bast, A.; Stahl, W.; Heyman, E.; Meeusen, R. Acute cocoa flavanols intake has minimal effects on exercise-induced oxidative stress and nitric oxide production in healthy cyclists: A randomized controlled trial. J. Int. Soc. Sports Nutr. 2017, 14, 28. [CrossRef]

166. Boarescu, P.M.; Boarescu, I.; Bocșan, I.C.; Pop, R.M.; Gheban, D.; Bulboacă, A.E.; Nicula, C.; Râjnoveanu, R.M.; Bolboacă, S.D. Curcumin Nanoparticles protect against isoproterenol induced myocardial infarction by alleviating myocardial tissue oxidative stress, electrocardiogram, and biological changes. Molecules 2019, 24, 2802. [CrossRef]

167. Boarescu, P.M.; Chirilă, I.; Bulboacă, A.E.; Bocșan, I.C.; Pop, R.M.; Gheban, D.; Bolboacă, S.D. Effects of curcumin nanoparticles in isoproterenol-induced myocardial infarction. Oxid. Med. Cell. Longev. 2019, 2019, 7847142. [CrossRef] [PubMed]

168. Boarescu, P.M.; Boarescu, I.; Bocșan, I.C.; Gheban, D.; Bulboacă, A.E.; Nicula, C.; Pop, R.M.; Râjnoveanu, R.M.; Bolboacă, S.D. Antioxidant and anti-inflammatory effects of curcumin nanoparticles on drug-induced acute myocardial infarction in diabetic rats. Antioxidants 2019, 8, 504. [CrossRef]

169. Hewlings, S.J.; Kalman, D.S. Curcumin: A review of its effects on human health. Foods 2017, 6, 92. [CrossRef]

170. Ray, A.; Rana, S.; Banerjee, D.; Mitra, A.; Datta, R.; Naskar, S.; Sarkar, S. Improved bioavailability of targeted Curcumin delivery efficiently regressed cardiac hypertrophy by modulating apoptotic load within cardiac microenvironment. Toxicol. Appl. Pharmacol. 2016, 290, 54-65. [CrossRef]

171. Penalva, R.; Esparza, I.; Larraneta, E.; González-Navarro, C.J.; Gamazo, C.; Irache, J.M. Zein-based nanoparticles improve the oral bioavailability of resveratrol and its anti-inflammatory effects in a mouse model of endotoxic shock. J. Agric. Food. Chem. 2015, 63, 5603-5611. [CrossRef]

172. Monaco, C.; Nanchahal, J.; Taylor, P.; Feldmann, M. Anti-TNF therapy: Past, present and future. Int. Immunol. 2015, 27, 55-62. [CrossRef]

173. Penalva, R.; González-Navarro, C.J.; Gamazo, C.; Esparza, I.; Irache, J.M. Zein nanoparticles for oral delivery of quercetin: Pharmacokinetic studies and preventive anti-inflammatory effects in a mouse model of endotoxemia. Nanomedicine 2017, 13, 103-110. [CrossRef]

174. Beconcini, D.; Felice, F.; Zambito, Y.; Fabiano, A.; Piras, A.M.; Macedo, M.H.; Sarmento, B.; Di Stefano, R. Anti-inflammatory effect of cherry extract loaded in polymeric nanoparticles: Relevance of particle internalization in endothelial cells. Pharmaceutics 2019, 11, 500. [CrossRef]

175. Valizadeh, H.; Abdolmohammadi-Vahid, S.; Danshina, S.; Ziya Gencer, M.; Ammari, A.; Sadeghi, A.; Roshangar, L.; Aslani, S.; Esmaeilzadeh, A.; Ghaebi, M.; et al. Nano-curcumin therapy, a promising method in modulating inflammatory cytokines in COVID-19 patients. Int. Immunopharmacol. 2020, 89, 107088. [CrossRef]

176. Bansal, M. Cardiovascular disease and COVID-19. Diabetes Metab. Syndr. 2020, 14, 247-250. [CrossRef]

177. Daiber, A.; Hahad, O.; Andreadou, I.; Steven, S.; Daub, S.; Münzel, T. Redox-related biomarkers in human cardiovascular disease-classical footprints and beyond. Redox Biol. 2021, 42, 101875. [CrossRef] [PubMed]

178. Bulboacă, A.E.; Porfire, A.; Bolboacă, S.D.; Nicula, C.A.; Feștilă, D.G.; Roman, A.; Râjnoveanu, R.M.; Râjnoveanu, A.; Dogaru, G.; Boarescu, P.M.; et al. Protective effects of liposomal curcumin on oxidative stress/antioxidant imbalance, metalloproteinases 2 and -9 , histological changes and renal function in experimental nephrotoxicity induced by gentamicin. Antioxidants 2021, 10, 325. [CrossRef]

179. Wu, G.R.; Cheserek, M.; Shi, Y.H.; Shen, L.Y.; Yu, J.; Le, G.W. Elevated plasma dityrosine in patients with hyperlipidemia compared to healthy individuals. Ann. Nutr. Metab. 2015, 66, 44-50. [CrossRef] [PubMed]

180. Breuss, J.M.; Atanasov, A.G.; Uhrin, P. Resveratrol and its effects on the vascular system. Int. J. Mol. Sci. 2019, 20, 1523. [CrossRef] [PubMed]

181. Yücel, Ç.; Karatoprak, G.Ş.; Aktaş, Y. Nanoliposomal Resveratrol as a Novel Approach to Treatment of Diabetes Mellitus. J. Nanosci. Nanotechnol. 2018, 18, 3856-3864. [CrossRef]

182. Rozanska, D.; Regulska-Ilow, B. The significance of anthocyanins in the prevention and treatment of type 2 diabetes. Adv. Clin. Exp. Med. 2018, 27, 135-142. [CrossRef] [PubMed]

183. Lila, M.A.; Burton-Freeman, B.; Grace, M.; Kalt, W. Unraveling anthocyanin bioavailability for human health. Annu. Rev. Food. Sci. Technol. 2016, 7, 375-393. [CrossRef] [PubMed]

184. Colorado, D.; Fernandez, M.; Orozco, J.; Lopera, Y.; Muñoz, D.L.; Acín, S.; Balcazar, N. Metabolic Activity of Anthocyanin Extracts Loaded into Non-ionic Niosomes in Diet-Induced Obese Mice. Pharm. Res. 2020, 37. [CrossRef]

185. Wilkinson, L.J.; White, R.J.; Chipman, J.K. Silver and nanoparticles of silver in wound dressings: A review of efficacy and safety. J. Wound. Care. 2011, 20, 543-549. [CrossRef] [PubMed]

186. Sung, J.H.; Ji, J.H.; Park, J.D.; Song, M.Y.; Song, K.S.; Ryu, H.R.; Yoon, J.U.; Jeon, K.S.; Jeong, J.; Han, B.S.; et al. Subchronic inhalation toxicity of gold nanoparticles. Part. Fibre. Toxicol. 2011, 8, 16. [CrossRef]

187. Fröhlich, E.; Roblegg, E. Models for oral uptake of nanoparticles in consumer products. Toxicology 2012, 291, 10-17. [CrossRef] 
188. Saha, K.; Moyano, D.F.; Rotello, V.M. Protein coronas suppress the hemolytic activity of hydrophilic and hydrophobic nanoparticles. Mater Horiz. 2014, 2014. [CrossRef]

189. Kharazian, B.; Hadipour, N.L.; Ejtehadi, M.R. Understanding the nanoparticle-protein corona complexes using computational and experimental methods. Int. J. Biochem. Cell. Biol. 2016, 75, 162-174. [CrossRef]

190. Higashisaka, K.; Nagano, K.; Yoshioka, Y.; Tsutsumi, Y. Nano-safety research: Examining the associations among the biological effects of nanoparticles and their physicochemical properties and kinetics. Biol. Pharm. Bull. 2017, 40, 243-248. [CrossRef]

191. EFSA Scientific Committee; Hardy, A.; Benford, D.; Halldorsson, T.; Jeger, M.J.; Knutsen, H.K.; More, S.; Naegeli, H.; Noteborn, H.; Ockleford, C.; et al. Guidance on risk assessment of the application of nanoscience and nanotechnologies in the food and feed chain: Part 1, human and animal health. EFSA J. 2018, 16, 5327. [CrossRef]

192. Siegrist, S.; Cörek, E.; Detampel, P.; Sandström, J.; Wick, P.; Huwyler, J. Preclinical hazard evaluation strategy for nanomedicines. Nanotoxicology 2019, 13, 73-99. [CrossRef] [PubMed]

193. Food and Drug Administration (FDA). PART 182 Substances generally recognized as safe. In Code of Federal Regulations; Title 21, Volume 3, Cite: 21CFR182, Revised on 1 April 2021; Food and Drug Administration (FDA): Silver Spring, MD, USA, 2021.

194. Idrees, H.; Zaidi, S.Z.J.; Sabir, A.; Khan, R.U.; Zhang, X.; Hassan, S.U. A review of biodegradable natural polymer-based nanoparticles for drug delivery applications. Nanomaterials 2020, 10, 1970. [CrossRef]

195. Barenholz, Y.C. Doxil@—the first FDA-approved nano-drug: Lessons learned. J. Control. Release 2012, 160, 117-134. [CrossRef]

196. D’Mello, S.R.; Cruz, C.N.; Chen, M.L.; Kapoor, M.; Lee, S.L.; Tyner, K.M. The evolving landscape of drug products containing nanomaterials in the United States. Nat. Nanotechnol. 2017, 12, 523-529. [CrossRef]

197. Siddiqui, I.A.; Adhami, V.M.; Chamcheu, J.C.; Mukhtar, H. Impact of nanotechnology in cancer: Emphasis on nanochemoprevention. Int. J. Nanomed. 2012, 7, 591-605. [CrossRef]

198. Dolati, S.; Ahmadi, M.; Aghebti-Maleki, L.; Nikmaram, A.; Marofi, F.; Rikhtegar, R.; Ayromlou, H.; Yousefi, M. Nanocurcumin is a potential novel therapy for multiple sclerosis by influencing inflammatory mediators. Pharmacol. Rep. 2018, 70, 1158-1167. [CrossRef] [PubMed]

199. Lee, W.H.; Bebawy, M.; Loo, C.Y.; Luk, F.; Mason, R.S.; Rohanizadeh, R. Fabrication of curcumin micellar nanoparticles with enhanced anti-cancer activity. J. Biomed. Nanotechnol. 2015, 11, 1093-1105. [CrossRef]

200. Kotha, R.R.; Luthria, D.L. Curcumin: Biological, pharmaceutical, nutraceutical, and analytical aspects. Molecules 2019, 24, 2930. [CrossRef] [PubMed]

201. European Parliament and the Council of the European Union. Directive 2010/63/eu of the european parliament and of the council of 22 september 2010 on the protection of animals used for scientific purposes. OJEU 2010, 53, 33-79.

202. Felice, F.; Zambito, Y.; Belardinelli, E.; D'Onofrio, C.; Fabiano, A.; Balbarini, A.; Di Stefano, R. Delivery of natural polyphenols by polymeric nanoparticles improves the resistance of endothelial progenitor cells to oxidative stress. Eur. J. Pharm. Sci. 2013, 50, 393-399. [CrossRef]

203. Bhushani, J.A.; Karthik, P.; Anandharamakrishnan, C. Nanoemulsion based delivery system for improved bioaccessibility and Caco-2 cell monolayer permeability of green tea catechins. Food Hydrocoll. 2016, 56, 372-382. [CrossRef]

204. Wang, G.; Wang, J.J.; Tang, X.J.; Du, L.; Li, F. In vitro and in vivo evaluation of functionalized chitosan-Pluronic micelles loaded with myricetin on glioblastoma cancer. Nanomedicine 2016, 12, 1263-1278. [CrossRef] [PubMed]

205. Sharifi, S.; Behzadi, S.; Laurent, S.; Forrest, M.L.; Stroeve, P.; Mahmoudi, M. Toxicity of nanomaterials. Chem. Soc. Rev. 2012, 41, 2323-2343. [CrossRef] [PubMed]

206. Saifi, M.A.; Khan, W.; Godugu, C. Cytotoxicity of nanomaterials: Using nanotoxicology to address the safety concerns of nanoparticles. Pharm. Nanotechnol. 2018, 6, 3-16. [CrossRef]

207. Siddique, M.I.; Katas, H.; Jamil, A.; Mohd Amin, M.C.I.; Ng, S.F.; Zulfakar, M.H.; Nadeem, S.M. Potential treatment of atopic dermatitis: Tolerability and safety of cream containing nanoparticles loaded with hydrocortisone and hydroxytyrosol in human subjects. Drug Deliv. Transl. Res. 2017, 9, 469-481. [CrossRef] [PubMed]

208. Asadi, S.; Gholami, M.S.; Siassi, F.; Qorbani, M.; Khamoshian, K.; Sotoudeh, G. Nano curcumin supplementation reduced the severity of diabetic sensorimotor polyneuropathy in patients with type 2 diabetes mellitus: A randomized double-blind placebocontrolled clinical trial. Complement. Ther. Med. 2019, 43, 253-260. [CrossRef]

209. Polack, F.P.; Thomas, S.J.; Kitchin, N.; Absalon, J.; Gurtman, A.; Lockhart, S.; Perez, J.L.; Pérez-Marc, G.; Moreira, E.D.; Zerbini, C.; et al. Safety and Efficacy of the BNT162b2 mRNA Covid-19 Vaccine. N. Engl. J. Med. 2020, 383, 2603-2615. [CrossRef]

210. Baden, L.R.; El Sahly, H.M.; Essink, B.; Kotloff, K.; Frey, S.; Novak, R.; Diemert, D.; Spector, S.A.; Rouphael, N.; Creech, C.B.; et al. Efficacy and Safety of the mRNA-1273 SARS-CoV-2 Vaccine. N. Engl. J. Med. 2021, 384, 403-416. [CrossRef]

211. Hassett, K.J.; Benenato, K.E.; Jacquinet, E.; Lee, A.; Woods, A.; Yuzhakov, O.; Himansu, S.; Deterling, J.; Geilich, B.M.; Ketova, T.; et al. Optimization of lipid nanoparticles for intramuscular administration of mRNA vaccines. Mol. Ther. Nucleic Acids 2019, 15, 1-11. [CrossRef]

212. Pardi, N.; Tuyishime, S.; Muramatsu, H.; Kariko, K.; Mui, B.L.; Tam, Y.K.; Madden, T.D.; Hope, M.J.; Weissman, D. Expression kinetics of nucleoside-modified mRNA delivered in lipid nanoparticles to mice by various routes. J. Control. Release 2015, 217, 345-351. [CrossRef] 